Psihologijske teme, 29 (2020), 3, 649-685

Izvorni znanstveni rad

UDK: $159.95 .072-057.875$

https://doi.org/10.31820/pt.29.3.9

$81 ' 23$

\title{
Norme za semantičke kategorije na hrvatskome jeziku
}

\author{
Maja Kućar, Valnea Žauhar, Igor Bajšanski, Dražen Domijan
}

Sveučilište u Rijeci, Filozofski fakultet, Odsjek za psihologiju, Rijeka, Hrvatska

\author{
Tanja Gulan
}

Osnovna škola Benkovac, Benkovac, Hrvatska

\section{Sažetak}

U ovome su radu prikazane norme za semantičke kategorije koje se pojavljuju u svakodnevnome jeziku. Popis 64 kategorije preuzet je iz normi na engleskome jeziku (Van Overschelde i sur., 2004), a dodane su još dvije kategorije. U istraživanju su sudjelovala 194 ispitanika $(M=38$, $\breve{Z}=156)$, većinom studenti Sveučilišta u Rijeci $(92.3 \%)$. Zadatak ispitanika bio je navesti četiri tipična pripadnika za svaku kategoriju, a odgovori su bilježeni pomoću računala. U radu su prikazane mjere koje opisuju status kategorije, a to su ukupan broj navedenih entiteta (pripadnika kategorije), broj entiteta $\mathrm{s}$ frekvencijom jednakom ili većom od deset, broj visokofrekventnih entiteta čija je proporcija pojavljivanja jednaka ili veća od .80 te indeks konzistentnosti odgovaranja. Naveden je i rang kategorija prema indeksu konzistentnosti odgovaranja. Osim toga, za svaku su kategoriju prikazani odgovori s frekvencijom pojavljivanja jednakom ili većom od deset, a za svaki je navedeni entitet prikazana proporcija pojavljivanja, zatim proporcija pojavljivanja na prvome mjestu te prosječni rang položaja odgovora unutar pojedine kategorije. Izrađene norme za semantičke kategorije predstavljaju metodološki alat za ujednačavanje i sistematizaciju jezičnih podražaja koji će biti od koristi u budućim istraživanjima iz kognitivne psihologije, psiholingvistike i srodnih područja na hrvatskome jeziku.

Ključne riječi: semantičke kategorije, norme, jezik, jezični materijal

\section{Uvod}

Kategorizacija okoline jedna je od temeljnih funkcija ljudske kognicije. Funkcija je kategorizacije organiziranje ili isticanje svojstava ekvivalentnosti među entitetima ili pripadnicima kategorija na osnovi zajedničkih obilježja, sličnosti ili neke druge pravilnosti koja ih povezuje. Znanje o kategorijama mentalno je reprezentirano. Bez sposobnosti za formiranje kategorija i za korištenje takvih mentalnih reprezentacija čovjekova bi se okolina doimala kaotičnom,

Valnea Žauhar, Odsjek za psihologiju, Filozofski fakultet, Sveučilište u Rijeci, Sveučilišna avenija 4, 51000 Rijeka. E-pošta: vzauhar@ffri.hr 
nepredvidljivom i nestrukturiranom (Ashby i Maddox, 2005; Murphy, 2002). Pritom je svaka kategorija određena svojim imenom, što znači da je kategorizacija kodirana u jeziku. Stjecanje uvida u ljudsku kategorizaciju moguće je ispitivanjem jezičnoga ponašanja ispitanika.

S ciljem standardizacije jezičnoga materijala izrađuju se norme koje prikazuju parametre koji opisuju karakteristike riječi (npr. učestalost, konkretnost, asocijativna snaga). Korištenje standardiziranoga jezičnog materijala nužno je kako bi se osigurala metodološka kontrola faktora koji mogu utjecati na izvedbu ispitanika. Za hrvatski su jezik recentno izrađene norme za afektivnost i konkretnost 3022 imenice (Ćoso i sur., 2019). U izradi je i Hrvatska psiholingvistička baza koja trenutno broji 6000 riječi i sadrži podatke o konkretnosti, predočivosti, relativnoj frekvenciji i dobi usvajanja tih riječi, zatim podatke o vrsti i duljini riječi, rodu i živosti imenica te frekvenciji riječi u internetskome korpusu hrvatskoga jezika hrWaC (http://megahr.ffzg.unizg.hr; Peti-Stantić i sur., 2018). U hrvatskome jeziku semantičke kategorije zasad nisu normirane.

Norme za kategorije pokušaj su izračunavanja i predviđanja tipičnoga, očekivanoga ili standardnoga jezičnog ponašanja izvornih govornika nekoga jezika. One predstavljaju istraživački alat koji obuhvaća kategorije koje se najčešće koriste u svakodnevnome jeziku. Izradom normi dobivaju se statistički parametri koji s jedne strane opisuju kategorije u cjelini, a s druge strane opisuju svaki odgovor ili svakoga pripadnika kategorije zasebno. Norme za kategorije omogućuju precizniju kontrolu jezičnoga podražajnog materijala i sustavnija istraživanja koja koriste verbalni materijal u kognitivnoj psihologiji, psiholingvistici i drugim područjima psihologije te srodnih znanosti. Primjeri istraživanja (Emberson i sur., 2019; Francis i sur., 2018; Rawson i Zamary, 2019) mogu se odnositi na ispitivanje pamćenja, kategorizacije, dvojezičnosti i jezičnih sposobnosti različitih populacija, od djece do starijih ispitanika te oboljelih od neurodegenerativnih bolesti. Norme za kategorije koriste se i za ispitivanje međukulturalnih razlika u različitim aspektima kognicije poput procjena poznatosti riječi, imenovanja slika ili suglasnosti oko značenja pojmova (Yoon i sur., 2004). Osim toga, norme za kategorije mogu biti korisne pri izradi rječnika te u obrazovanju i u konstrukciji materijala za učenje stranoga jezika (Hernández-Muñoz i sur., 2006).

Kod izrade normi za kategorije cilj je utvrditi koji su tipični ili najreprezentativniji predstavnici neke kategorije (Battig i Montague, 1969; Cohen i sur., 1957). Jedan je od načina ispitivanja tipičnosti izravnim procjenjivanjem zadanih pripadnika neke kategorije. $\mathrm{U}$ tome slučaju ispitanici pridavanjem brojčane oznake, primjerice, na skali od 1 do 7 , procjenjuju koliko dobro pojedini pripadnik kategorije predstavlja njihovu ideju zadane kategorije. Izračunom prosjeka tih procjena utvrđuje se da su neki pripadnici bolji predstavnici svoje kategorije od drugih pripadnika. Tipičnost se može ispitati i tako da se od ispitanika traži da unutar zadanoga vremenskog okvira navedu što veći broj pripadnika kategorije. U tome se 
slučaju pokazuje da se neki pripadnici pojavljuju češće i da se uobičajeno ti pripadnici navode među prvima u nizu (npr. Mervis i sur., 1976).

Pri izradi normi za kategorije koriste se dvije metode ispitivanja tipičnosti. Jedna je navođenje što više pripadnika kategorije unutar zadanoga vremenskog okvira. Brojna istraživanja pritom koriste vremenski okvir od 30 sekundi (npr. Battig i Montague, 1969; Bueno i Megherbi, 2009; Castro i sur., 2020; Marchenko i sur., 2015; Marshall i Parr, 1996; Van Overschelde i sur., 2004), a može se koristiti i vremenski okvir od 60 sekundi (Marful i sur., 2015). Druga se metoda odnosi na navođenje četiriju ili pet tipičnih pripadnika kategorije bez vremenskoga ograničenja (Cohen i sur., 1957; Kantner i Lindsay, 2014; Yoon i sur., 2004). Metoda navođenja što više pripadnika kategorije unutar nekoga vremenskog okvira rezultira prikupljanjem veće količine podataka, ali i veće količine neiskoristivoga materijala jer kod te metode postoji veći rizik da će ispitanici producirati asocijacije. Kod metode navođenja ograničenoga broja pripadnika ispitanici su usmjereni na razmišljanje o tipičnosti i reprezentativnosti pripadnika. Kantner i Lindsay (2014) stoga navode da je metoda navođenja ograničenoga broja pripadnika praktičnija za provedbu, pripremu podataka za obradu i za analizu.

Iako obje metode imaju svojih prednosti i nedostataka, McEvoy i Nelson (1982) navode kako je opažena tipičnost pripadnika vrlo malo, ako uopće jest, pod utjecajem navedenih metodoloških varijacija u prikupljanju podataka. Naime, tipičnost je robustan fenomen i podjednaki se pripadnici kategorije izdvajaju kao tipični prilikom korištenja različitih vrsta zadataka navođenja pripadnika (s vremenskim ograničenjem ili bez njega, $\mathrm{s}$ uputom da je potrebno navesti isključivo tipične pripadnike ili bez takve upute). Također, istovjetni se rezultati dobivaju i korištenjem zadataka verifikacije tvrdnji i slika, pri kojima je vrijeme verifikacije značajno kraće, a točnost značajno veća za tipične nego za ostale pripadnike neke kategorije (npr. Fujihara i sur., 1998; Rips i sur., 1973; Rosch, 1973). Sve navedeno ukazuje na to da tipičnost kao karakteristika pripadnika kategorija ima istaknut status u kognitivnome sustavu. Tipični su pripadnici oni koji ispitanicima u trenutku pretraživanja mentalnih kategorija bivaju brzo i konzistentno dostupni. Zbog njezine ekonomičnosti po pitanju provedbe i pripreme podataka za obradu, a uzevši u obzir da je tipičnost robustan fenomen koji se zahvaća korištenjem različitih metoda prikupljanja podataka, u ovome je istraživanju korištena metoda navođenja četiriju tipičnih pripadnika kategorije.

\section{Parametri koji opisuju kategorije i entitete unutar kategorija}

Norme za kategorije prikazuju parametre koji opisuju kategorije u cjelini i pojedine pripadnike unutar svake kategorije zasebno. Uobičajeno, za svakoga se pripadnika kategorije prikazuje proporcija ili frekvencija njegova pojavljivanja $\mathrm{u}$ uzorku te proporcija ili frekvencija pojavljivanja na prvome mjestu prilikom navođenja pripadnika kategorije. Ako se neki pripadnik kategorije kod većine 
ispitanika pojavljuje na prvome mjestu, to govori o svojevrsnoj povlaštenosti toga odgovora unutar kognitivnoga sustava. Na primjer, neka kategorija može imati tri dominantna pripadnika koje navode gotovo svi ispitanici, no činjenica da se jedan pripadnik češce pojavljuje na prvome mjestu, a druga dva na drugome i trećemu mjestu govori o tome da ta tri entiteta nisu ekvivalentna, iako bismo gledajući proporcije pojavljivanja to mogli zaključiti. Mjera koja se također vezuje uz redoslijed navođenja pripadnika rang je položaja odgovora unutar kategorije. Ako je korištena metoda navođenja četiriju tipičnih predstavnika kategorije, onda će rang položaja odgovora ovisiti o frekvenciji pojavljivanja toga odgovora na prvome, drugome, trećemu i četvrtome mjestu. Za izračunavanje ranga položaja odgovora potrebno je pomnožiti frekvenciju pojavljivanja na određenome mjestu (prvome, drugome, trećemu ili četvrtome) s ordinalnom pozicijom mjesta (jedan, dva, tri ili četiri), četiri dobivena umnoška zbrojiti te konačno podijeliti $s$ ukupnom frekvencijom pojavljivanja toga odgovora. Još jedan parametar koji je moguće prikazati mjera je leksičke dostupnosti. Leksička je dostupnost indeks koji mjeri lakoću dosjećanja određenoga odgovora, a temelji se na ordinalnome položaju odgovora unutar svoje kategorije, broju ispitanika koji su producirali odgovor i najvišemu položaju na kojemu je odgovor produciran (najviši je mogući položaj prvo mjesto). Veći leksički indeks znači da je odgovor bio u prosjeku produciran ranije i češće. U nekim se normama kod prikaza parametara za pripadnike kategorije navode i podaci o vremenu potrebnome za produciranje odgovora (Van Overschelde i sur., 2004).

Osim parametara koji opisuju pripadnike kategorije, norme prikazuju i parametre prema kojima se kategorije u cjelini međusobno razlikuju. Primjerice, dva entiteta mogu biti najtipičniji predstavnici svojih kategorija, no njihove kategorije mogu biti različito raspršene, odnosno jedna može imati veći varijabilitet od druge. Raspršenost kategorije vidljiva je na temelju ukupnoga broja navedenih entiteta za pojedinu kategoriju ili na temelju potencije kategorije. Potencija kategorije prikazuje se kada se koristi metoda navođenja pripadnika unutar zadanoga vremenskog okvira. Ona označava koliko entiteta u prosjeku ispitanici navode za pojedinu kategoriju. Kategorije se prema potenciji mogu i rangirati, i to tako da se prvi rang dodjeljuje kategoriji u kojoj je producirano prosječno najviše odgovora (Battig i Montague, 1969; Van Overschelde i sur., 2004).

Norme za kategorije na engleskome jeziku izradili su Battig i Montague (1969), potaknuti normama koje su već 1957. izradili Cohen i suradnici. U istraživanju Cohena i suradnika (1957) normirane su 43 kategorije, a neke su od njih bile dragi kamen, gorivo, alkoholno piće, ples, glazbeni instrument, dio građevine i sport. Battig i Montague (1969) preuzeli su 43 inicijalno korištene kategorije te uveli dodatnih 13 kategorija (rođak, vrsta teksta, kuhinjski pribor, jedinica govora, politička funkcija, vrsta novca, vrsta glazbe, bezalkoholno piće, vrsta igračke, žensko ime, grad, američka savezna država, koledžlsveučilište). Objavljeni normirani podaci o kategorijama korišteni su u istraživanjima različitih aspekata 
kognicije, a rad je citiran više od 2500 puta u više od 200 različitih časopisa (Van Overschelde i sur., 2004), što govori u prilog nužnosti postojanja takvoga tipa normiranih podataka o kategorijama u okviru nekoga jezika. S obzirom na to da je uporaba jezika, osobito svakidašnjega, dinamična i kontinuirano se mijenja tijekom vremena, Van Overschelde i suradnici (2004) nakon više od trideset godina ponovno su normirali kategorije te dodali novih 14 kategorija onima korištenima $\mathrm{u}$ istraživanju Battiga i Montaguea (1969). Dio dodanih kategorija bile su općenite (lijek, automobil), a dio specifične za neku domenu (pozicija u američkome nogometu, kazna u američkome nogometu, ime momčadi američkoga nogometa, vrtlarski alat i biljka). Još jedan dio dodatnih kategorija bile su one koje su cilju usmjerene i/ili one koje se stvaraju u trenutku, tzv. ad hoc kategorije (tekućina, ženski odjevni predmet, objekt koji leti, predmet koji stvara buku, predmet zelene boje, drveni predmet, predmet koji iznosimo iz kuć u plamenu). Svim je kategorijama zajedničko da se koriste u svakodnevnome jeziku.

Usporedbom normi koje su izradili Van Overschelde i suradnici (2004) i onih ranijih (Battig i Montague, 1969) te najrecentnijih normi (Castro i sur., 2020) pokazuje se da su one generacijski većinom stabilne. Iznimke su kategorije čiji su se najreprezentativniji pripadnici promijenili uslijed društvenih promjena i trendova (npr. vrsta plesa, žensko ime, muško ime, vrsta goriva i savezna država, bolest, igračka, vrsta glazbe). Van Overschelde i suradnici (2004) kao primjer navode kako su se valcer i frug istaknuli kao najpopularniji plesovi u ranijim normama (Battig i Montague, 1969), dok su u njihovim normama to balet i tango. Pritom napominju kako je prosječan sudionik prvoga istraživanja rođen sredinom 40-ih godina, dok je prosječan sudionik njihova istraživanja rođen 80 -ih godina 20. stoljeća. Društvene promjene i protok vremena utječu na uporabu određenih pojmova, a u skladu s time razvidno je da se tipičnost pripadnika kategorije može mijenjati kroz vrijeme, a može se razlikovati i s obzirom na mjesto ispitivanja (Marshall i Parr, 1996; Van Overschelde i sur., 2004). U tome se slučaju računaju korelacije kao mjere povezanosti, odnosno podudarnosti rezultata u dvama gradovima ili u dvjema različitima vremenskim točkama mjerenja. Opisani se parametri nazivaju mjerama geografske i vremenske stabilnosti.

Iako je velik dio semantičkoga znanja o kategorijama koje se ispituju podjednak i univerzalan u svim jezicima, specifičnosti različitih jezika, mijenjanje jezika kroz vrijeme, osjetljivost jezika na društvene promjene, kulturološke varijacije i drugi iskustveni čimbenici mogu značajno mijenjati pojavnost nekih pojmova, pa i čitavih kategorija u jeziku. S obzirom na to da se jezik, semantička struktura i međupovezanost pojmova u pamćenju u određenoj mjeri razlikuju u različitim kulturama, američke se norme ne mogu u potpunosti generalizirati na druge države, jezike ili kulture (Kantner i Lindsay, 2014). Po uzoru na norme koje su izradili Battig i Montague (1969) norme za kategorije izrađene su u mnogim državama, a neke su od njih Kanada (Kanter i Lindsay, 2014), Novi Zeland (Marshall i Parr, 1996), Francuska (Bueno i Megherbi, 2009), Rusija (Marchenko i sur., 2015) i Španjolska 
(Marful i sur., 2015). Kao što je već navedeno, za hrvatski jezik takve norme dosad nisu bile priređene.

Stoga je cilj ovoga rada upravo prikaz normi za semantičke kategorije na hrvatskome jeziku izrađenih na temelju ispitivanja tipičnih pripadnika za 66 kategorija većinom preuzetih iz normi na engleskome jeziku (Van Overschelde i sur., 2004).

\section{Metoda}

\section{Ispitanici}

U istraživanju su sudjelovala 194 izvorna govornika hrvatskoga jezika, 156 ženskoga te 38 muškog roda. Prosječna je dob ispitanika 22.23 godine $(S D=6.45)$.

Studenti Filozofskoga fakulteta u Rijeci informirani su o provedbi istraživanja i zamoljeni da na sudjelovanje potaknu i studente drugih fakulteta i prijatelje. Jedini uvjet za sudjelovanje u istraživanju bio je da ispitanik bude izvorni govornik hrvatskoga jezika. Sudjelovanje u istraživanju bilo je dobrovoljno.

Većina ispitanika koji su sudjelovali u istraživanju studenti su Sveučilišta u Rijeci (92.3\%), a mali je udio ispitanika koji su zaposleni (7.7 \%). Među studentima najzastupljeniji su bili oni s Filozofskoga fakulteta (75\%), a mali je udio studenata drugih fakulteta (oko $5 \%$ s Ekonomskoga, Tehničkoga i Medicinskog fakulteta te manje od $5 \%$ s Učiteljskoga, Pomorskoga i Pravnog fakulteta, Fakulteta za menadžment i turizam te Sveučilišnih odjela). Ispitanici dolaze iz različitih regija diljem Hrvatske. Najviše je ispitanika iz grada Rijeke $(25 \%)$ i s područja sjeverozapadne Hrvatske (32\%). Svi su ispitanici u trenutku sudjelovanja u istraživanju stanovali u Rijeci i okolici.

\section{Instrumentarij}

U istraživanju je korišten popis kategorija preuzet iz normi na engleskome jeziku (Van Overschelde i sur., 2004). Četiri izvorna govornika hrvatskoga jezika odvojeno su prevela nazive kategorija. Za većinu naziva kategorija postignuta je jednoglasna suglasnost ( $72 \%$ kategorija), a za kategorije kod kojih su postojale dvije ili više verzija prijevoda prevoditelji su zajednički donijeli odluku o najprikladnijemu prijevodu. Pet kategorija isključeno je s popisa zbog toga što su specifične za američku kulturu i uobičajeno se ne koriste $\mathrm{u}$ istraživanjima na hrvatskome jeziku (američka savezna država, koledž, pozicija u američkome nogometu, kazna u američkome nogometu, ime momčadi američkoga nogometa). Jedna je kategorija isključena zbog sadržajne specifičnosti (predmet zelene boje). Za potrebe su ovoga istraživanja dodane dvije kategorije - kategorija hrvatski grad, jer je uobičajeno dodati takvu vrstu kategorije u svakoj državi u kojoj je normiranje 
provedeno, i kategorija kućni ljubimac, kako bi se uveo primjer kategorije koja je sadržajno usporediva s nekom drugom kategorijom (a to je u ovome radu kategorija četveronožna životinja). Popis ukupno 66 kategorija korištenih u ovome istraživanju nalazi se u Tablici 1. Redoslijed navođenja kategorija u Tablici 1. usklađen je s onime Van Overscheldea i suradnika (2004) kako bi se olakšala usporedba. Istraživanje je pripremljeno i provedeno u računalnome programu LimeSurvey.

\section{Postupak}

Istraživanje je provedeno grupno u računalnoj učionici Filozofskoga fakulteta u Rijeci. Istraživanju je istovremeno pristupalo u prosjeku 20 ispitanika. Na početku istraživanja ispitanicima je usmeno dana uputa koja je bila prikazana i na ekranu računala. Zadatak ispitanika bio je napisati četiri tipična pripadnika prezentirane kategorije u za to predviđena polja na računalu služeći se tipkovnicom. U uputi je naveden primjer kategorije planet i njezini potencijalni tipični pripadnici: Zemlja, Mars, Jupiter, Venera. Naglašeno je da je potrebno navoditi isključivo tipične pripadnike kategorija te da nije potrebno navoditi rijetke ili neobične odgovore. Redoslijed prikazivanja kategorija bio je slučajan za svakoga ispitanika. Vrijeme odgovaranja nije bilo ograničeno.

\section{Rezultati i rasprava}

\section{Priprema podataka za obradu}

Podaci su pripremljeni za obradu temeljem naputaka preuzetih iz prethodnih istraživanja (Battig i Montague, 1969; Kantner i Lindsay, 2014; Marshall i Par, 1996; Van Overschelde i sur., 2004). Prije statističke analize prikupljenih podataka ispravljene su pravopisne i gramatičke pogreške te su odgovori ujednačeni. To se odnosi na ujednačavanje odgovora koji označavaju isti pojam, ali su napisani u jednini ili množini, u različitim padežima, malim ili velikim slovima te bez dijakritičkih znakova. U Prilogu su odgovori prikazani u jednini, u nominativu. Sinonimi su prikazani kao združen odgovor, ali i pojedinačno. Na taj je način vidljivo jesu li se oba odgovora navodila podjednako često ili je jedan odgovor navođen češće (npr. mamalmajka).

Netočni odgovori koji su rezultat nerazumijevanja zadatka ili kategorije ili koji se odnose na navođenje asocijacija isključeni su iz analize (npr. vrsta teksta - ravan, okomit, kurziv, podcrtan). Iz navedenoga se razloga broj ispitanika koji su navodili pripadnike kategorija prikazan u Tablici 1. u nekim kategorijama razlikuje. Ipak, neki su odgovori uključeni u analizu iako nisu najtočniji predstavnici svoje kategorije. Na primjer, unutar kategorije biljka kao odgovor je zadržano drvo, iako drvo zapravo nije vrsta biljke, a u kategoriji kemijski element zadržana je voda, iako je ona kemijski spoj, a ne element. Ukupno je iz analize isključeno $1.6 \%$ odgovora. 
Raspon postotka odgovora isključenih iz pojedine kategorije kretao se od $0 \%$ do $11.34 \%$. Pritom su kategorije s najvećim postotkom isključenih odgovora sakralni objekt, geološka tvorevina i predmet koji iznosimo iz kuće u plamenu (> $10 \%$ isključenih odgovora), a slijedi kategorija vrsta teksta (7.22 \%). Kod takvih bi kategorija u budućim istraživanjima bilo poželjno dodati pojašnjenje prilikom prikupljanja podataka. Na primjer, uz kategoriju vrsta teksta Yoon i suradnici (2004) ispitanicima su pojasnili da nije prikladno navoditi naslove (književnih) djela.

\section{Podaci koji opisuju status kategorija}

U Tablici 1. prikazane su sve kategorije uključene $u$ istraživanje te parametri koji opisuju svaku kategoriju. Po uzoru na druge norme (npr. Bueno i Megherbi, 2009) prikazan je broj ispitanika koji su naveli tipične pripadnike za pojedinu kategoriju. Nadalje, prikazan je ukupan broj navedenih entiteta u pojedinoj kategoriji jer u tablicama u Prilogu nisu navedeni svi entiteti. Naime, običaj je navoditi samo entitete koje je navelo minimalno $5 \%$ ispitanika, a preostali se entiteti smatraju rijetkim ili jedinstvenim odgovorima. Neovisno o tome, ukupan broj entiteta koji se navode za svaku kategoriju informativan je pokazatelj raspršenja pojedine kategorije. Kako bi se kategorije pobliže opisale i lakše međusobno uspoređivale, naveden je i broj entiteta čija je frekvencija jednaka ili veća od deset te broj visokofrekventnih entiteta (proporcija pojavljivanja veća od .80). Ti podaci mogu biti osobito korisni za istraživanja u domeni kategorizacije. Nakraju, za svaku je kategoriju prikazan indeks konzistentnosti odgovaranja. Indeks konzistentnosti odgovaranja predstavlja udio broja entiteta čija je frekvencija pojavljivanja jednaka ili veća od deset u ukupnome broju navedenih entiteta unutar jedne kategorije. Takva mjera odražava međusobno slaganje ispitanika prilikom navođenja entiteta pojedine kategorije i informativan je pokazatelj sličnosti, ali i raznovrsnosti kategorijalnih reprezentacija. Na primjer, za kategorije s manjim brojem tipičnih predstavnika i jasnom hijerarhijskom kategorijalnom strukturom (npr. član obitelji, boja, kućni ljubimac) očekivano je da ispitanici daju vrlo konzistentne odgovore. Za kategorije s manje jasnom hijerarhijskom strukturom i većim brojem potencijalnih pripadnika (npr. lijek, zločin) očekivano je da će odgovaranje ispitanika biti znatno manje konzistentno. Prema indeksu konzistentnosti kategorije su i rangirane, i to tako da je kategoriji s najvećom konzistentnošću odgovaranja dodijeljen rang 1.

Ukupan broj entiteta govori o opsegu i varijabilitetu same kategorije. Ta je mjera pod utjecajem stvarne brojnosti pripadnika kategorije, odnosno širine kategorije. Također, ovisi i o tome koliko je kategorija bliska ispitanicima, odnosno koliko je njihovo znanje o njoj jer je dokumentirano da predznanje ispitanika utječe na njihovo odgovaranje (za detalje v. Murphy, 2002; Rawson i Van Overschelde, 2008). Za kategorije s velikim brojem navedenih entiteta može se zaključiti da znanje o toj kategoriji među ispitanicima više varira. Osim toga, moguće je da ispitanici imaju slično opće znanje o nekoj opširnoj kategoriji, ali se međusobno 
Kućar, M., Žauhar, V., Bajšanski, I., Domijan, D., Gulan, T.:

Norme za semantičke kategorije

Tablica 1.

Prikaz normiranih kategorija i parametara vezanih za svaku kategoriju

\begin{tabular}{|c|c|c|c|c|c|c|}
\hline Kategorija & $\begin{array}{c}\text { Broj } \\
\text { ispita- } \\
\text { nika }\end{array}$ & $\begin{array}{c}\text { Broj } \\
\text { entiteta }\end{array}$ & $\begin{array}{c}\text { Broj } \\
\text { entiteta čija } \\
\text { je } \\
\text { frekvencija } \\
\geq 10\end{array}$ & $\begin{array}{c}\text { Broj } \\
\text { visokofre- } \\
\text { kventnih } \\
\text { entiteta } \\
(>.80)\end{array}$ & $\begin{array}{l}\text { Indeks } \\
\text { konzisten } \\
\text {-tnosti }\end{array}$ & $\begin{array}{c}\text { Rang } \\
\text { (prema } \\
\text { indeksu } \\
\text { konzisten- } \\
\text { tnosti) }\end{array}$ \\
\hline 1. Dragi kamen & 187 & 37 & 11 & 0 & .30 & 31.5 \\
\hline 2. Jedinica vremena & 192 & 23 & 7 & 3 & .30 & 31.5 \\
\hline 3. Član obitelji & 193 & 10 & 8 & 2 & .80 & 1 \\
\hline 4. Mjera udaljenosti & 192 & 16 & 8 & 3 & .50 & 5 \\
\hline 5. Metal & 190 & 29 & 10 & 1 & .34 & 21.5 \\
\hline 6. Vrsta teksta & 180 & 117 & 16 & 0 & .14 & 61 \\
\hline 7. Vojni čin & 184 & 46 & 14 & 0 & .30 & 31.5 \\
\hline 8. Četveronožna životinja & 193 & 29 & 13 & 2 & .45 & 8 \\
\hline 9. Tkanina & 192 & 35 & 14 & 1 & .40 & 11 \\
\hline 10. Boja & 192 & 11 & 8 & 4 & .73 & 2 \\
\hline 11. Kuhinjski pribor & 194 & 32 & 8 & 3 & .25 & 36 \\
\hline 12. Sakralni objekt & 172 & 75 & 14 & 0 & .19 & 52.5 \\
\hline 13. Vrsta riječi & 193 & 23 & 8 & 3 & .35 & 19 \\
\hline 14. Namještaj & 193 & 34 & 8 & 1 & .24 & 38.5 \\
\hline 15. Dio ljudskoga tijela & 193 & 33 & 12 & 3 & .36 & 16 \\
\hline 16. Voće & 194 & 28 & 12 & 1 & .43 & 9 \\
\hline 17. Oružje & 192 & 50 & 12 & 3 & .24 & 38.5 \\
\hline 18. Politička funkcija & 189 & 53 & 11 & 1 & .21 & 49.5 \\
\hline 19. Nastamba & 192 & 58 & 12 & 1 & .21 & 49.5 \\
\hline 20. Alkoholno piće & 193 & 35 & 12 & 1 & .34 & 21.5 \\
\hline 21. Država & 192 & 43 & 16 & 1 & .37 & 14 \\
\hline 22. Zločin & 192 & 80 & 9 & 2 & .11 & 65.5 \\
\hline 23. Stolarski alat & 188 & 72 & 16 & 0 & .22 & 45 \\
\hline 24. Pripadnik svećenstva & 186 & 33 & 12 & 0 & .36 & 16 \\
\hline 25. Začin & 194 & 43 & 14 & 2 & .33 & 24.5 \\
\hline 26. Gorivo & 190 & 33 & 12 & 1 & .36 & 16 \\
\hline 27. Zanimanje & 193 & 108 & 19 & 0 & .18 & 54 \\
\hline 28. Geološka tvorevina & 173 & 91 & 14 & 0 & .15 & 58.5 \\
\hline 29. Sport & 193 & 33 & 8 & 1 & .24 & 38.5 \\
\hline 30. Meteorološki fenomen & 182 & 72 & 17 & 0 & .24 & 38.5 \\
\hline 31. Odjevni predmet & 192 & 34 & 11 & 2 & .32 & 27.5 \\
\hline 32. Dio građevine & 188 & 52 & 12 & 0 & .23 & 41.5 \\
\hline 33. Kemijski element & 194 & 39 & 19 & 0 & .49 & 6 \\
\hline 34. Glazbeni instrument & 193 & 25 & 12 & 1 & .48 & 7 \\
\hline 35. Vrsta novca & 192 & 37 & 13 & 2 & .35 & 19 \\
\hline 36. Vrsta glazbe & 193 & 43 & 13 & 1 & .30 & 31.5 \\
\hline 37. Ptica & 192 & 47 & 13 & 0 & .28 & 35 \\
\hline 38. Bezalkoholno piće & 194 & 39 & 13 & 0 & .33 & 24.5 \\
\hline 39. Vozilo & 190 & 26 & 10 & 1 & .38 & 13 \\
\hline
\end{tabular}




\begin{tabular}{|c|c|c|c|c|c|c|}
\hline Kategorija & $\begin{array}{c}\text { Broj } \\
\text { ispita- } \\
\text { nika }\end{array}$ & $\begin{array}{c}\text { Broj } \\
\text { entiteta }\end{array}$ & $\begin{array}{c}\text { Broj } \\
\text { entiteta čija } \\
\text { je } \\
\text { frekvencija } \\
\geq 10\end{array}$ & $\begin{array}{c}\text { Broj } \\
\text { visokofre- } \\
\text { kventnih } \\
\text { entiteta } \\
(>.80)\end{array}$ & $\begin{array}{l}\text { Indeks } \\
\text { konzisten } \\
\text {-tnosti }\end{array}$ & $\begin{array}{c}\text { Rang } \\
\text { (prema } \\
\text { indeksu } \\
\text { konzisten- } \\
\text { tnosti) }\end{array}$ \\
\hline 40. Znanost & 190 & 45 & 10 & 0 & .22 & 45 \\
\hline 41. Igračka & 193 & 69 & 12 & 0 & .17 & 55 \\
\hline 42. Ples & 192 & 42 & 14 & 1 & .33 & 24.5 \\
\hline 43. Povrće & 193 & 34 & 19 & 0 & .56 & 3.5 \\
\hline 44. Obuća & 194 & 22 & 9 & 1 & .41 & 10 \\
\hline 45. Kukac & 193 & 36 & 14 & 0 & .39 & 12 \\
\hline 46. Žensko ime & 193 & 95 & 14 & 0 & .15 & 58.5 \\
\hline 47. Muško ime & 193 & 94 & 11 & 1 & .12 & 64 \\
\hline 48. Cvijet & 194 & 42 & 14 & 0 & .33 & 24.5 \\
\hline 49. Bolest & 194 & 105 & 17 & 0 & .16 & 56.5 \\
\hline 50. Stablo & 189 & 43 & 15 & 0 & .35 & 19 \\
\hline 51. Brod & 190 & 48 & 14 & 0 & .29 & 34 \\
\hline 52. Riba & 193 & 68 & 15 & 0 & .22 & 45 \\
\hline 53. Zmija & 193 & 31 & 10 & 0 & .32 & 27.5 \\
\hline 54. Grad & 190 & 72 & 15 & 0 & .21 & 49.5 \\
\hline 55. Lijek & 193 & 141 & 15 & 0 & .11 & 65.5 \\
\hline 56. Automobil & 192 & 74 & 16 & 0 & .22 & 45 \\
\hline 57. Tekućina & 193 & 61 & 13 & 1 & .21 & 49.5 \\
\hline 58. Ženska odjeća & 194 & 48 & 11 & 2 & .23 & 41.5 \\
\hline 59. Objekt koji leti & 193 & 54 & 17 & 1 & .31 & 29 \\
\hline $\begin{array}{l}\text { 60. Predmet koji stvara } \\
\text { buku }\end{array}$ & 193 & 119 & 19 & 0 & .16 & 56.5 \\
\hline 61. Drveni predmet & 193 & 86 & 11 & 1 & .13 & 63 \\
\hline $\begin{array}{l}\text { 62. Predmet koji iznosimo } \\
\text { iz kuće u plamenu }\end{array}$ & 173 & 100 & 14 & 0 & .14 & 61 \\
\hline 63. Vrtlarski alat & 194 & 63 & 12 & 0 & .19 & 52.5 \\
\hline 64. Biljka & 191 & 135 & 19 & 0 & .14 & 61 \\
\hline 65. Hrvatski grad* & 194 & 36 & 8 & 2 & .22 & 45 \\
\hline 66. Kućni ljubimac* & 193 & 18 & 10 & 2 & .56 & 3.5 \\
\hline
\end{tabular}

* kategorije koje su dodane u ovome istraživanju

razlikuju prema tome kojih će se pripadnika kategorije lakše dosjetiti. S jedne strane, oslanjanje na dostupnost je opravdano jer je frekventnije entitete i događaje lakše zamisliti i dosjetiti ih se od onih manje frekventnih. S druge strane, sama dostupnost pod utjecajem je različitih faktora koji nisu nužno povezani s frekvencijom pojavljivanja nekoga entiteta. Valja se podsjetiti da je ispitanicima u uputi napomenuto da navode najtipičnije pripadnike zadanih kategorija te da nikako ne navode posebne, atipične i originalne odgovore. Na taj su način ispitanici upozoreni da entitet kojega se prvoga dosjete ne mora nužno, ali i može biti najtipičniji predstavnik zadane kategorije. Za kategorije s manjim ukupnim brojem navedenih 
entiteta može se reći da su uže. Manji ukupni broj navedenih entiteta može odražavati stvarnu ograničenost broja pripadnika kategorije, ali može odražavati i sličnost u znanju ispitanika. To znači da kod navođenja pripadnika takvih kategorija većina ispitanika slično razmišlja te sukladno tomu sličnije i odgovara.

Nadalje, za svaku su kategoriju izdvojeni pripadnici čija je frekvencija pojavljivanja jednaka ili veća od deset, a izračunan je i udio tih entiteta u ukupnome broju navedenih entiteta unutar jedne kategorije (indeks konzistentnosti odgovaranja). Visoka negativna povezanost između ukupnoga broja entiteta i indeksa konzistentnosti odgovaranja, $r=-.76$, potvrđuje da je konsenzus u odgovaranju veći za uže kategorije.

Konačno, za svaku je kategoriju izdvojen broj visokofrekventnih entiteta, i to onih koje navodi najmanje $80 \%$ ispitanika. Visokofrekventni predstavnici najbolji su predstavnici kategorija, a razlike u broju visokofrekventnih pripadnika, između ostaloga, ukazuju na razlike u strukturi kategorija. U prikazanim normama 31 kategorija nema niti jednoga visokofrekventnog pripadnika, 19 ih ima po jednoga, devet po dva, šest po tri, a samo su u jednoj kategoriji zabilježena četiri visokofrekventna pripanika. Korelacija između broja visokofrekventnih entiteta i indeksa konzistentnosti umjerena je i pozitivna, $r=.42$, što također potvrđuje veći konsenzus odgovaranja u užim kategorijama. Jedina kategorija koja ima četiri visokofrekventna pripadnika kategorija je boja. Ona nije opširna, odnosno u njoj je navedeno ukupno tek 11 pripadnika, a indeks konzistentnosti odgovaranja za tu je kategoriju visok i iznosi .73. Navedeno sugerira da su pripadnici kategorije boja međusobno ekvivalentni, za razliku od pripadnika neke druge, šire kategorije kod koje je indeks odgovaranja niži (npr. u kategoriji sport pripadnici nogomet i košarka nisu ekvivalentni gimnastici i hokeju).

\section{Podaci koji opisuju status pripadnika kategorija}

U nastavku su prikazane mjere koje se odnose na status pripadnika unutar kategorije. U Prilogu su za svaku kategoriju prikazani odgovori čija je frekvencija bila jednaka ili veća od deset. Ta je granica arbitrarna, odnosno postavljena je isključivo radi preglednosti rada i po uzoru na ranije objavljene norme (Battig i Montague, 1969; Van Overschelde i sur., 2004). Naime, uobičajeno je navoditi one entitete koje je navelo barem 5 \% ispitanika (Bueno i Megherbi, 2009; Castro i sur., 2020). Po uzoru na druge norme i radi mogućnosti usporedbe u Prilogu je za svaki entitet prikazana proporcija pojavljivanja pojedinoga odgovora i proporcija pojavljivanja pojedinoga odgovora na prvome mjestu. Parametri su izraženi u proporcijama, a ne u frekvencijama radi lakše usporedbe između kategorija te zbog nejednakoga broja ispitanika. U Prilogu je prikazan i prosječan rang položaja svakoga odgovora unutar kategorije.

Ukupna proporcija pojavljivanja nekoga entiteta jednostavna je mjera koja najtočnije prikazuje tipičnost nekoga entiteta unutar kategorije. Nastavno na tu 
mjeru, proporcija pojavljivanja na prvome mjestu može poslužiti kao svojevrstan detektor prototipičnosti nekoga pripadnika. Ako dva entiteta imaju sličnu, vrlo visoku proporciju pojavljivanja, ali su kod jednoga pripadnika ukupna proporcija i proporcija pojavljivanja na prvome mjestu gotovo jednake, a kod drugoga nisu, to znači da je prvi pripadnik tipičniji predstavnik kategorije.

Rang položaja odgovora pokazuje na kojemu se mjestu u prosjeku pojavljuje navedeni odgovor. Što je rang manji, odnosno bliži broju 1, odgovor se pojavljuje ranije. Ta je mjera u nekim slučajevima korisna, primjerice, dva odgovora mogu imati istu proporciju pojavljivanja, a različit rang. $U$ tome je slučaju rang korisna mjera jer pokazuje koji je odgovor superiorniji između tih dvaju, što nije moguće iščitati iz proporcije. $\mathrm{S}$ druge strane, ta je mjera pod utjecajem same proporcije pojavljivanja odgovora. Neki prikazani odgovori imaju vrlo malu proporciju pojavljivanja (npr. .05), a visoko su rangirani. U tome bi slučaju bilo neopravdano oslanjati se na rang kao mjeru koja govori o tome koliko je taj pripadnik dobar predstavnik kategorije. Odgovor koji ima visoku proporciju pojavljivanja, a nije visoko rangiran i dalje je bolji predstavnik te kategorije, stoga je kod rangova važno uzeti u obzir ostale mjere. Moguće je pretpostaviti da je informativnost ranga kao mjere utoliko veća ukoliko je veća proporcija pojavljivanja toga odgovora.

Zaključno o statističkim parametrima za kategorije i za pojedinačne odgovore valja istaknuti da ih treba sagledavati zajedno jer uzimanje u obzir samo jednoga parametra može navesti na krive zaključke.

\section{Zaključak, ograničenja ovoga istraživanja i prijedlozi za buduća istraživanja}

Prikazane norme za kategorije sadrže parametre koji opisuju same kategorije te navedene pripadnike kategorija. Norme za kategorije predstavljaju istraživački alat kojim se omogućuje sustavniji odabir jezičnoga materijala za provedbu budućih istraživanja na hrvatskome jeziku.

U ovome je istraživanju korištena metoda navođenja četiriju tipičnih pripadnika kategorije. Metoda navođenja četiriju tipičnih pripadnika ekonomičnija je od navođenja što većega broja pripadnika u zadanome vremenskom okviru, no ograničenje je te metode da se dio znanja ispitanika o kategoriji ne obuhvaća, odnosno da se dio informacija propušta jer je broj pripadnika koji se mogu navesti uvijek ograničen na četiri. U budućim bi istraživanjima valjalo usporediti dobivene rezultate s rezultatima iz drugih država (npr. Bueno i Megherbi, 2009; Castro i sur., 2020; Marchenko i sur., 2015; Van Overshelde i sur., 2004). Kod takve uspredbe za velik bi se broj kategorija očekivalo značajno preklapanje jer ispitanici u različitim kulturama dijele semantičko znanje o svakodnevnim kategorijama. Na primjer, usporedbom entiteta navedenih u kategoriji boja u ovome radu i u američkim normama (Van Overshelde i sur., 2004) moguće je zamijetiti da su četiri najfrekventnija entiteta identična i na istim pozicijama (plava, crvena, zelena, žuta). 
Vrlo slična raspodjela uočava se i u španjolskim (Marful i sur., 2015) i u francuskim normama (Bueno i Megherbi, 2009). Kao još jedan primjer može se navesti kategorija četveronožna životinja u kojoj se na prvim trima mjestima i u istome poretku u američkim (Van Overshelde i sur., 2004) i španjolskim (Marful i sur., 2015), kao i u normama prikazanima u ovome radu, nalaze entiteti pas, mačka i konj.

U određenim kategorijama zasićenima specifičnim znanjem koje je pod utjecajem sociokulturoloških razlika očekivala bi se odstupanja. Usporedbom sadržaja kategorija prezentiranih u ovome radu i u američkim normama (Van Overshelde i sur., 2004) moguće je uočiti razlike u, primjerice, kategoriji sport. U američkim normama najpopularniji je sport američki nogomet, na popisu nema rukometa, a pri samome je vrhu bejzbol. U normama iz ovoga istraživanja najpopularniji je sport nogomet, rukomet je drugi po redu, a bejzbola nema na popisu. Razlike u sadržaju kategorija očekivano su vidljive u kategorijama kao što su novac, muško ime, žensko ime, grad te politička funkcija. Zanimljivo, u američkome je istraživanju najtipičniji meteorološki fenomen tornado, dok je u ovome istraživanju kiša. Rap i rock (and roll) najtipičnije su vrste glazbe koje se navode u američkome istraživanju, dok se u ovome istraživanju rock navodi kao najtipičnija vrsta glazbe, a rap je tek na petome mjestu. Također, najtipičniji ples u ovome je istraživanju valcer, dok je u američkome balet, a valcer je tek na šestome mjestu.

Potrebno je još jednom napomenuti da su u ovome istraživanju sudjelovali ispitanici iz svih dijelova Hrvatske, većinom studenti koji studiraju na Sveučilištu u Rijeci. Norme za kategorije na određenome jeziku trebaju predstavljati presjek jezičnoga ponašanja ispitivane skupine ispitanika pa je stoga dobro da su u istraživanju sudjelovali govornici različitih hrvatskih narječja i njihovih dijalekata. Ipak, zamjetna je prevaga ispitanika iz Rijeke ( $25 \%$ uzorka), što je moguće utjecalo na odgovaranje ispitanika u nekim kategorijama. Na primjer, prema ovim rezultatima Rijeka je drugi najtipičniji predstavnik kategorija grad i hrvatski grad. Za provjeru geografske stabilnosti rezultata predlaže se normiranje u glavnome gradu Zagrebu ili u jednome od preostalih dvaju regionalnih centara - Osijeku ili Splitu. Iako se normiranje semantičkih kategorija u drugome gradu preporuča, ne očekuju se velika geografska odstupanja zbog geografske stabilnosti u dosadašnjim istraživanjima koja su rađena u mnogo većim državama od Hrvatske (Marchenko i sur., 2015; Marshall i Parr., 1996; Van Overschelde i sur., 2004).

Također, u velikoj mjeri i iz istih razloga očekivala bi se i vremenska stabilnost rezultata, osobito kod kategorija koje nisu podložne društvenim promjenama i trendovima (npr. voće, član obitelji). Međutim, iako nije neuobičajeno da kod normiranja jezičnoga materijala ispitanici budu studenti (npr. Battig i Montague, 1969; Kantner i Lindsay, 2014; Van Overshelde i sur., 2004), takav uzorak ima ograničenja. Naime, iako se usporedbom frekvencija pojavljivanja entiteta unutar kategorija normiranih u različitim istraživanjima pokazuje da je semantičko znanje uvelike podudarno kroz generacije (npr. Yoon i sur., 2004), najrecentnije norme (Castro i sur., 2020) pokazuju da se barem kod nekih kategorija varijabilnost 
semantičkoga znanja opaža tek kad se uspoređuju redoslijedi navođenja entiteta unutar kategorija. Moguće je da je jedan entitet naveden jednako često kod uzorka mlađih i starijih ispitanika, no da se prosječni rang ili redoslijed navođenja istoga entiteta kod različitih uzoraka razlikuje. Navedeno potencijalno ukazuje na to da je prioritet pojedinih entiteta različit kod različitih generacija, ali i na to da se dostupnost entiteta u semantičkome pamćenju mijenja sa starenjem. Na primjer, u najrecentnijim američkim normama pokazalo se da su i mlađi i stariji ispitanici podjednako često navodili računalne znanosti kao pripadnika kategorije znanost, no mlađi su ispitanici taj odgovor navodili ranije. Iz toga razloga sljedeće bi normiranje semantičkih kategorija na hrvatskome jeziku valjalo provesti na starijim ispitanicima kako bi se moglo utvrditi u kojoj su mjeri odgovori starijih ispitanika podudarni s odgovorima mlađih ispitanika. Može se očekivati da bi se kod većine kategorija zamijetila visoka podudarnost odgovaranja, no isto tako i da bi se kod jednoga dijela kategorija primijetile razlike. Takve je razlike važno uzeti u obzir i kontrolirati prilikom ispitivanja jezične izvedbe ispitanika različite životne dobi.

Zaključno, norme na hrvatskome jeziku valjalo bi obnavljati vodeći računa o tome da je jezik dinamičan te da su neke jezične domene podložnije vremenskim promjenama od drugih.

\section{Literatura}

Ashby, F. G. i Maddox, W. T. (2005). Human category learning. Annual Review of Psychology, 56, 149-178. https://doi.org/10.1146/annurev.psych.56.091103.070217

Battig, W. F. i Montague, W. E. (1969). Category norms of verbal items in 56 categories: A replication and extension of the Connecticut category norms. Journal of Experimental Psychology, 80(32), 1-46. https://doi.org/10.1037/h0027577

Bueno, S. i Megherbi, H. (2009). French categorization norms for 70 semantic categories and comparison with Van Overschelde et al.'s (2004) English norms. Behavior Research Methods, 41(4), 1018-1028. https://doi.org/10.3758/BRM.41.4.1018

Castro, N., Curley, T. i Hertzog, C. (2020). Category norms with a cross-sectional sample of adults in the United States: Consideration of cohort, age, and historical effects on semantic categories. Behavior Research Methods, 1-20. https://doi.org/10.3758/ s13428-020-01454-9

Cohen, B. H., Bousfield, W. A. i Whitmarsh, G. A. (1957). Cultural norms for verbal items in 43 categories. University of Connecticut.

Ćoso, B., Guasch, M., Ferré, P. i Hinojosa, J. A. (2019). Affective and concreteness norms for 3,022 Croatian words. Quarterly Journal of Experimental Psychology, 72(9), 23022312. https://doi.org/10.1177/1747021819834226 
Emberson, L. L., Loncar, N., Mazzei, C., Treves, I. i Goldberg, A. E. (2019). The blowfish effect: Children and adults use atypical exemplars to infer more narrow categories during word learning. Journal of Child Language, 46(5), 938-954. https://doi.org/10. 1017/S0305000919000266

Francis, W. S., Taylor, R. S., Gutiérrez, M., Liaño, M. K., Manzanera, D. G. i Penalver, R. M. (2018). The effects of bilingual language proficiency on recall accuracy and semantic clustering in free recall output: Evidence for shared semantic associations across languages. Memory, 26(10), 1364-1378. https://doi.org/10.1080/09658211. 2018.1476551

Fujihara, N., Nageishi, Y., Koyama, S. i Nakajima, Y. (1998). Electrophysiological evidence for the typicality effect of human cognitive categorization. International Journal of Psychophysiology, 29(1), 65-75. https://doi.org/10.1016/s0167-8760(97)00099-8

Hernández-Muñoz, N., Izura, C. i Ellis, A. W. (2006). Cognitive aspects of lexical availability. European Journal of Cognitive Psychology, 18(5), 730-755. https://doi.org/10.1080/09541440500339119

Kantner, J. i Lindsay, D. S. (2014). Category exemplars normed in Canada. Canadian Journal of Experimental Psychology/Revue canadienne de psychologie expérimentale, 68(3), 163-165. https://doi.org/10.1037/cep0000023

Marchenko, O. P., Bandurka, T. N. i Pavlov, Y. G. (2016). Geographical stability of category norms for Russian language. Russian Linguistic Bulletin, 4(8), 12-16. https://doi.org/10.18454/RULB.8.25

Marful, A., Díez, E. i Fernandez, A. (2015). Normative data for the 56 categories of Battig and Montague (1969) in Spanish. Behavior Research Methods, 47(3), 902-910. https://doi.org/10.3758/s13428-014-0513-8

Mervis, C. B., Catlin, J. i Rosch, E. (1976). Relationships among goodness-of-example, category norms, and word frequency. Bulletin of the Psychonomic Society, 7(3), 283284. https://doi.org/10.3758/BF03337190

Marshall, C. E. i Parr, W. V. (1996). New Zealand norms for a subset of Battig and Montague's (1969) categories. New Zealand Journal of Psychology, 25(1), 24-29.

McEvoy, C. L. i Nelson, D. L. (1982). Category name and instance norms for 106 categories of various sizes. The American Journal of Psychology, 4, 581-634. https://doi.org/10. $2307 / 1422189$

Murphy, G. (2002). The big book of concepts. MIT press.

Peti-Stantić, A., Anđel, M., Keresteš, G., Ljubešić, N., Stanojević, M. M. i Tonković, M. (2018). Psiholingvističke mjere ispitivanja 3.000 riječi hrvatskoga jezika: Konkretnost i predočivost. Suvremena lingvistika, 44(85), 91-112. https://doi.org/10.22210/suvlin. 2018.085.05

Rawson, K. A. i Van Overschelde, J. P. (2008). How does knowledge promote memory? The distinctiveness theory of skilled memory. Journal of Memory and Language, 58(3), 646-668. https://doi.org/10.1016/j.jml.2007.08.004 
Rawson, K. A. i Zamary, A. (2019). Why is free recall practice more effective than recognition practice for enhancing memory? Evaluating the relational processing hypothesis. Journal of Memory and Language, 105, 141-152. https://doi.org/10.1016/ j.jml.2019.01.002

Rips, L. J., Shoben, E. J. i Smith, E. E. (1973). Semantic distance and the verification of semantic relations. Journal of Verbal Learning and Verbal Behavior, 12(1), 1-20. https://doi.org/10.1016/S0022-5371(73)80056-8

Rosch, E. (1973). On the internal structure of perceptual and semantic categories. U: T. E. Moore (Ur.), Cognitive Development and the acquisition of language (str. 111-144). Academic Press.

Van Overschelde, J. P., Rawson, K. A. i Dunlosky, J. (2004). Category norms: An updated and expanded version of the Battig and Montague (1969) norms. Journal of Memory and Language, 50(3), 289-335. https://doi.org/10.1016/j.jml.2003.10.003

Yoon, C., Feinberg, F., Hu, P., Gutchess, A. H., Hedden, T., Chen, H. Y. M. i Park, D. C. (2004). Category norms as a function of culture and age: Comparisons of item responses to 105 categories by american and chinese adults. Psychology and Aging, 19(3), 379393. https://doi.org/10.1037/0882-7974.19.3.379

\title{
Norms for Semantic Categories in the Croatian Language
}

\begin{abstract}
In this paper, norms for semantic categories used in Croatian everyday language are presented. We used the list of 64 categories from the norms in English language (Van Overschelde et al., 2004), and 2 categories were added to the list. In the study participated 194 subjects $(\mathrm{M}=38, \mathrm{~F}=$ 156), mainly students of the University of Rijeka (92.3\%). The participants had to list four typical exemplars for each presented category. Measures that describe the status of each category are shown: total number of entities, number of entities with a frequency higher or equal to ten, number of high-frequency entities whose proportion is equal to or higher than .80 , and response consistency index. Categories were ranked according to the response consistency indexes. Furthermore, for each category, entities with a frequency higher or equal to ten are presented, and the proportion, proportion of appearing in the first place, and the mean rank of the position of the response are presented for each entity. Category norms are a methodological research tool that can be used for systematization of verbal stimuli in future research in the Croatian language in the area of cognitive psychology, psycholinguistics and related fields.
\end{abstract}

Keywords: semantic categories, norms, language, verbal material

Primljeno: 13. 3. 2020. 
Kućar, M., Žauhar, V., Bajšanski, I., Domijan, D., Gulan, T.:

Prilog

Proporcije pojavljivanja i rang položaja odgovora unutar kategorija

\begin{tabular}{|c|c|c|c|c|}
\hline Kategorija & Entitet & $\begin{array}{c}\text { Učestalost } \\
\text { pojavljivanja } \\
\text { odgovora }(\mathrm{p})\end{array}$ & $\begin{array}{c}\text { Učestalost } \\
\text { pojavljivanja } \\
\text { odgovora na } 1 . \\
\text { mjestu (p) }\end{array}$ & $\begin{array}{c}\text { Rang } \\
\text { položaja } \\
\text { odgovora }\end{array}$ \\
\hline 1. & Rubin & .74 & .23 & 2.08 \\
\hline \multirow[t]{10}{*}{ Dragi kamen } & Dijamant & .70 & .30 & 2.02 \\
\hline & Safir & .56 & .15 & 2.26 \\
\hline & Smaragd & .35 & .07 & 2.65 \\
\hline & Dragulj & .17 & .06 & 2.09 \\
\hline & Ametist & .12 & .04 & 2.32 \\
\hline & Biser & .10 & .02 & 2.84 \\
\hline & Opal & .09 & .02 & 2.82 \\
\hline & Kristal & .08 & .02 & 2.60 \\
\hline & Zlato & .06 & .01 & 3.18 \\
\hline & Srebro & .05 & .02 & 2.30 \\
\hline 2. & Sat & .94 & .39 & 2.09 \\
\hline Jedinica & Sekunda & .92 & .39 & 2.03 \\
\hline \multirow[t]{5}{*}{ vremena } & Minuta & .89 & .16 & 2.04 \\
\hline & Dan & .41 & .01 & 3.63 \\
\hline & Milisekunda & .27 & .01 & 3.46 \\
\hline & Godina & .18 & .01 & 3.63 \\
\hline & Stotinka & .15 & .01 & 3.55 \\
\hline 3. & Mama/Majka & .99 & .81 & 1.24 \\
\hline \multirow[t]{11}{*}{ Član obitelji } & Mama & .61 & .54 & 1.15 \\
\hline & Majka & .39 & .27 & 1.37 \\
\hline & Tata/Otac & .98 & .11 & 1.98 \\
\hline & Tata & .60 & .02 & 2.08 \\
\hline & Otac & .39 & .09 & 1.84 \\
\hline & Brat & .71 & .05 & 3.11 \\
\hline & Sestra & .66 & .03 & 3.54 \\
\hline & Baka & .20 & .01 & 3.53 \\
\hline & Sin & .15 & .01 & 3.07 \\
\hline & Kći & .14 & & 3.78 \\
\hline & Djed & .12 & & 3.71 \\
\hline 4. & Metar & .99 & .76 & 1.35 \\
\hline Mjera & Kilometar & .86 & .07 & 2.68 \\
\hline \multirow[t]{6}{*}{ udaljenosti } & Centimetar & .81 & .09 & 2.61 \\
\hline & Milimetar & .57 & .07 & 3.11 \\
\hline & Milja & .28 & & 3.30 \\
\hline & Decimetar & .15 & & 3.28 \\
\hline & Inč & .10 & & 2.63 \\
\hline & Stopa & .10 & & 3.15 \\
\hline
\end{tabular}


PSIHOLOGIJSKE TEME, 29 (2020), 3, 649-685

\begin{tabular}{|c|c|c|c|c|}
\hline Kategorija & Entitet & $\begin{array}{c}\text { Učestalost } \\
\text { pojavljivanja } \\
\text { odgovora }(p)\end{array}$ & $\begin{array}{c}\text { Učestalost } \\
\text { pojavljivanja } \\
\text { odgovora na } 1 . \\
\text { mjestu (p) }\end{array}$ & $\begin{array}{c}\text { Rang } \\
\text { položaja } \\
\text { odgovora }\end{array}$ \\
\hline \multirow{10}{*}{$\begin{array}{l}5 . \\
\text { Metal }\end{array}$} & Željezo & .87 & .56 & 1.56 \\
\hline & Bakar & .60 & .08 & 2.54 \\
\hline & Aluminij & .44 & .09 & 2.54 \\
\hline & Zlato & .43 & .08 & 2.72 \\
\hline & Srebro & .39 & .02 & 2.85 \\
\hline & Cink & .19 & .03 & 2.81 \\
\hline & Čelik & .18 & .04 & 2.56 \\
\hline & Olovo & .17 & .03 & 2.53 \\
\hline & Bronca & .11 & .02 & 2.62 \\
\hline & Živa & .06 & .01 & 2.83 \\
\hline 6. & Roman & .43 & .19 & 2.01 \\
\hline \multirow{15}{*}{ Vrsta teksta } & Pjesma & .41 & .12 & 2.26 \\
\hline & Esej & .27 & .09 & 2.33 \\
\hline & Članak & .26 & .07 & 2.28 \\
\hline & Proza & .21 & .09 & 1.68 \\
\hline & Pripovijetka & .17 & .02 & 3.00 \\
\hline & Poezija & .16 & .06 & 1.79 \\
\hline & Novinski članak & .10 & .03 & 2.39 \\
\hline & Znanstveni tekst & .09 & .02 & 2.41 \\
\hline & Priča & .09 & .02 & 2.44 \\
\hline & Bajka & .09 & .02 & 2.94 \\
\hline & $\mathrm{Ep}$ & .09 & .01 & 2.76 \\
\hline & Novela & .09 & .01 & 3.06 \\
\hline & Knjiga & .07 & .03 & 1.69 \\
\hline & Drama & .07 & .01 & 3.08 \\
\hline & Basna & .07 & .01 & 3.25 \\
\hline \multirow{14}{*}{$\begin{array}{l}7 . \\
\text { Vojni čin }\end{array}$} & General & .67 & .31 & 1.95 \\
\hline & Vojnik & .53 & .12 & 2.43 \\
\hline & Pukovnik & .44 & .16 & 2.12 \\
\hline & Zapovjednik & .38 & .10 & 2.45 \\
\hline & Časnik & .28 & .07 & 2.37 \\
\hline & Činovnik & .16 & .04 & 2.48 \\
\hline & Satnik & .15 & .03 & 2.33 \\
\hline & Kapetan & .14 & .02 & 2.96 \\
\hline & Kadet & .12 & .04 & 2.50 \\
\hline & Narednik & .10 & .03 & 2.53 \\
\hline & Admiral & .10 & .02 & 2.68 \\
\hline & Bojnik & .10 & .01 & 2.63 \\
\hline & Poručnik & .07 & .01 & 2.69 \\
\hline & Vojni pilot & .05 & & 3.60 \\
\hline
\end{tabular}


Kućar, M., Žauhar, V., Bajšanski, I., Domijan, D., Gulan, T.:

Norme za semantičke kategorije

\begin{tabular}{|c|c|c|c|c|}
\hline Kategorija & Entitet & $\begin{array}{c}\text { Učestalost } \\
\text { pojavljivanja } \\
\text { odgovora }(\mathrm{p})\end{array}$ & $\begin{array}{c}\text { Učestalost } \\
\text { pojavljivanja } \\
\text { odgovora na } 1 . \\
\text { mjestu (p) }\end{array}$ & $\begin{array}{c}\text { Rang } \\
\text { položaja } \\
\text { odgovora }\end{array}$ \\
\hline 8. & Pas & .98 & .76 & 1.30 \\
\hline Četveronožna & Mačka & .93 & .15 & 1.95 \\
\hline \multirow[t]{11}{*}{ životinja } & Konj & .44 & .05 & 2.93 \\
\hline & Krava & .36 & .02 & 3.41 \\
\hline & Lav & .22 & & 3.38 \\
\hline & Svinja & .16 & .01 & 3.20 \\
\hline & Slon & .15 & .01 & 3.41 \\
\hline & Tigar & .15 & .01 & 3.46 \\
\hline & Vuk & .09 & .01 & 3.35 \\
\hline & Medvjed & .07 & & 3.43 \\
\hline & Miš & .06 & & 3.42 \\
\hline & Zec & .06 & & 3.58 \\
\hline & Koza & .05 & & 3.40 \\
\hline 9. & Pamuk & .94 & .48 & 1.64 \\
\hline \multirow[t]{13}{*}{ Tkanina } & Svila & .79 & .33 & 1.93 \\
\hline & Poliester & .37 & .02 & 3.03 \\
\hline & Vuna & .34 & .05 & 2.83 \\
\hline & Lan & .23 & .07 & 2.40 \\
\hline & Sintetika & .21 & .01 & 3.22 \\
\hline & Saten & .11 & .01 & 3.14 \\
\hline & Kašmir & .11 & & 3.24 \\
\hline & Koža & .10 & .01 & 3.25 \\
\hline & Traper & .09 & & 3.35 \\
\hline & Viskoza & .08 & & 3.44 \\
\hline & Til & .06 & .02 & 2.42 \\
\hline & Baršun & .06 & & 3.09 \\
\hline & Elastin & .06 & & 3.33 \\
\hline 10. & Plava & .97 & .26 & 2.17 \\
\hline \multirow[t]{7}{*}{ Boja } & Crvena & .96 & .56 & 1.67 \\
\hline & Zelena & .83 & .08 & 3.01 \\
\hline & Žuta & .80 & .03 & 3.25 \\
\hline & Crna & .11 & .03 & 2.48 \\
\hline & Roza & .10 & .02 & 2.60 \\
\hline & Ljubičasta & .10 & .02 & 2.95 \\
\hline & Bijela & .07 & .01 & 2.71 \\
\hline 11. & Nož & .86 & .39 & 2.10 \\
\hline \multirow[t]{7}{*}{ Kuhinjski pribor } & Vilica & .84 & .16 & 2.09 \\
\hline & Žlica & .82 & .24 & 2.24 \\
\hline & Kuhača & .45 & .15 & 2.77 \\
\hline & Tanjur & .32 & & 3.68 \\
\hline & Lonac & .21 & .04 & 2.60 \\
\hline & Tava & .08 & .01 & 3.06 \\
\hline & Šeflja & .06 & & 3.27 \\
\hline
\end{tabular}


PSIHOLOGIJSKE TEME, 29 (2020), 3, 649-685

\begin{tabular}{|c|c|c|c|c|}
\hline Kategorija & Entitet & $\begin{array}{c}\text { Učestalost } \\
\text { pojavljivanja } \\
\text { odgovora (p) }\end{array}$ & $\begin{array}{c}\text { Učestalost } \\
\text { pojavljivanja } \\
\text { odgovora na } 1 . \\
\text { mjestu (p) }\end{array}$ & $\begin{array}{c}\text { Rang } \\
\text { položaja } \\
\text { odgovora }\end{array}$ \\
\hline 12. & Crkva & .62 & .53 & 1.23 \\
\hline \multirow[t]{13}{*}{ Sakralni objekt } & Džamija & .38 & .01 & 2.65 \\
\hline & Križ & .30 & .13 & 2.08 \\
\hline & Kalež & .24 & .10 & 2.05 \\
\hline & Oltar & .24 & .08 & 2.39 \\
\hline & Katedrala & .18 & .01 & 2.87 \\
\hline & Sinagoga & .17 & & 3.00 \\
\hline & Hostija & .16 & .03 & 2.50 \\
\hline & Hram & .16 & .01 & 3.25 \\
\hline & Kapelica & .15 & & 2.92 \\
\hline & Samostan & .10 & & 2.67 \\
\hline & Krunica & .08 & .01 & 2.77 \\
\hline & Kapela & .07 & .01 & 2.75 \\
\hline & Svetište & .06 & & 3.45 \\
\hline 13. & Imenica & .98 & .83 & 1.22 \\
\hline \multirow{7}{*}{ Vrsta riječi } & Glagol & .94 & .08 & 2.32 \\
\hline & Pridjev & .92 & .05 & 2.79 \\
\hline & Zamjenica & .48 & .01 & 3.33 \\
\hline & Prilog & .25 & .01 & 3.79 \\
\hline & Broj & .10 & & 3.80 \\
\hline & Veznik & .08 & & 3.75 \\
\hline & Prijedlog & .07 & & 3.85 \\
\hline 14. & Stol & .88 & .33 & 2.02 \\
\hline \multirow[t]{7}{*}{ Namještaj } & Stolica & .79 & .10 & 2.56 \\
\hline & Kauč & .59 & .24 & 2.20 \\
\hline & Ormar & .56 & .14 & 2.71 \\
\hline & Krevet & .45 & .09 & 2.83 \\
\hline & Fotelja & .26 & .06 & 2.44 \\
\hline & Komoda & .07 & & 3.36 \\
\hline & Polica & .06 & & 3.55 \\
\hline 15. & Ruka & .94 & .47 & 1.69 \\
\hline Dio ljudskoga & Noga & .93 & .11 & 2.36 \\
\hline \multirow[t]{10}{*}{ tijela } & Glava & .80 & .33 & 2.21 \\
\hline & Trup & .23 & .01 & 3.45 \\
\hline & Oko & .16 & .03 & 2.94 \\
\hline & Vrat & .14 & .01 & 3.44 \\
\hline & Nos & .12 & .01 & 3.17 \\
\hline & Trbuh & .12 & .01 & 3.67 \\
\hline & Prst & .09 & & 3.83 \\
\hline & Uho & .07 & & 3.31 \\
\hline & Stopalo & .07 & & 3.46 \\
\hline & Usta & .05 & .01 & 3.10 \\
\hline
\end{tabular}


Kućar, M., Žauhar, V., Bajšanski, I., Domijan, D., Gulan, T.:

Norme za semantičke kategorije

\begin{tabular}{|c|c|c|c|c|}
\hline Kategorija & Entitet & $\begin{array}{c}\text { Učestalost } \\
\text { pojavljivanja } \\
\text { odgovora }(\mathrm{p})\end{array}$ & $\begin{array}{c}\text { Učestalost } \\
\text { pojavljivanja } \\
\text { odgovora na } 1 . \\
\text { mjestu (p) }\end{array}$ & $\begin{array}{c}\text { Rang } \\
\text { položaja } \\
\text { odgovora }\end{array}$ \\
\hline 16. & Jabuka & .97 & .69 & 1.39 \\
\hline \multirow[t]{11}{*}{ Voće } & Kruška & .72 & .09 & 2.26 \\
\hline & Banana & .62 & .08 & 2.80 \\
\hline & Naranča & .39 & .04 & 2.88 \\
\hline & Jagoda & .38 & .06 & 3.00 \\
\hline & Šljiva & .24 & .01 & 3.22 \\
\hline & Trešnja & .11 & .01 & 3.23 \\
\hline & Lubenica & .08 & .01 & 3.33 \\
\hline & Ananas & .06 & .01 & 2.92 \\
\hline & Breskva & .06 & .01 & 3.33 \\
\hline & Grožđe & .06 & & 3.42 \\
\hline & Limun & .06 & & 3.82 \\
\hline 17. & Pištolj & .96 & .58 & 1.53 \\
\hline \multirow{11}{*}{ Oružje } & Puška & .87 & .27 & 2.04 \\
\hline & Nož & .80 & .10 & 2.70 \\
\hline & Bomba & .28 & .01 & 3.37 \\
\hline & Mač & .13 & .02 & 3.04 \\
\hline & Tenk & .08 & .01 & 3.20 \\
\hline & Top & .07 & & 3.21 \\
\hline & Mitraljez & .07 & & 3.62 \\
\hline & Sjekira & .07 & & 3.62 \\
\hline & Snajper & .06 & & 3.27 \\
\hline & Palica & .06 & & 3.42 \\
\hline & Sačmarica & .06 & & 3.50 \\
\hline \multirow{11}{*}{$\begin{array}{l}18 . \\
\text { Politička } \\
\text { funkcija }\end{array}$} & $\begin{array}{l}\text { Predsjednik } \\
\text { države }\end{array}$ & .93 & .51 & 1.72 \\
\hline & Ministar & .65 & .20 & 2.25 \\
\hline & Premijer & .44 & .14 & 2.05 \\
\hline & Saborski zastupnik & .41 & .07 & 2.54 \\
\hline & Gradonačelnik & .30 & & 3.33 \\
\hline & Župan & .13 & & 3.24 \\
\hline & Predsjednik vlade & .11 & .02 & 2.62 \\
\hline & Predsjednik sabora & .11 & .01 & 2.75 \\
\hline & Potpredsjednik & .11 & & 2.80 \\
\hline & Načelnik & .08 & & 3.40 \\
\hline & Tajnik & .06 & & 3.36 \\
\hline 19. & Kuća & .95 & .77 & 1.26 \\
\hline \multirow[t]{6}{*}{ Nastamba } & Zgrada & .52 & .07 & 2.42 \\
\hline & Koliba & .51 & .06 & 2.66 \\
\hline & Stan & .42 & .04 & 2.40 \\
\hline & Neboder & .17 & .01 & 2.81 \\
\hline & Šator & .16 & & 3.29 \\
\hline & Vila & .11 & & 3.48 \\
\hline
\end{tabular}


PSIHOLOGIJSKE TEME, 29 (2020), 3, 649-685

\begin{tabular}{|c|c|c|c|c|}
\hline Kategorija & Entitet & $\begin{array}{c}\text { Učestalost } \\
\text { pojavljivanja } \\
\text { odgovora }(\mathrm{p})\end{array}$ & $\begin{array}{c}\text { Učestalost } \\
\text { pojavljivanja } \\
\text { odgovora na } 1 . \\
\text { mjestu }(p)\end{array}$ & $\begin{array}{c}\text { Rang } \\
\text { položaja } \\
\text { odgovora }\end{array}$ \\
\hline & Iglu & .10 & .01 & 3.37 \\
\hline & Spilja & .08 & .01 & 3.06 \\
\hline & Vikendica & .08 & & 3.50 \\
\hline & Zemunica & .06 & .01 & 3.18 \\
\hline & Hotel & .05 & & 3.80 \\
\hline \multirow{12}{*}{$\begin{array}{l}20 . \\
\text { Alkoholno piće }\end{array}$} & Vino & .81 & .17 & 2.18 \\
\hline & Pivo & .77 & .36 & 1.97 \\
\hline & Votka & .65 & .24 & 2.18 \\
\hline & Rakija & .42 & .03 & 3.23 \\
\hline & Viski & .32 & .05 & 2.73 \\
\hline & Jagermeister & .14 & .06 & 2.15 \\
\hline & Konjak & .12 & .01 & 3.35 \\
\hline & Rum & .11 & .02 & 2.90 \\
\hline & Džin & .11 & .01 & 3.10 \\
\hline & Pelinkovac & .10 & & 3.30 \\
\hline & Tekila & .09 & .02 & 2.94 \\
\hline & Štok & .07 & .02 & 2.85 \\
\hline \multirow{18}{*}{$\begin{array}{l}21 . \\
\text { Država }\end{array}$} & Hrvatska & .83 & .80 & 1.06 \\
\hline & Njemačka & .49 & .04 & 2.67 \\
\hline & Engleska/Velika & & & \\
\hline & $\begin{array}{l}\text { Britanija/ } \\
\text { Ujedinjeno } \\
\text { Kraljevstvo }\end{array}$ & .32 & .04 & 2.72 \\
\hline & Engleska & .18 & .02 & 2.68 \\
\hline & Velika Britanija & .08 & .01 & 2.93 \\
\hline & $\begin{array}{l}\text { Ujedinjeno } \\
\text { Kraljevstvo }\end{array}$ & .06 & .01 & 2.58 \\
\hline & Italija & .32 & .01 & 2.92 \\
\hline & $\begin{array}{l}\text { Sjedinjene } \\
\text { Američke Države }\end{array}$ & .30 & .05 & 2.61 \\
\hline & Francuska & .27 & .01 & 3.21 \\
\hline & Slovenija & .25 & .01 & 2.71 \\
\hline & Srbija & .22 & & 2.69 \\
\hline & Austrija & .11 & .01 & 3.09 \\
\hline & Rusija & .10 & .01 & 3.20 \\
\hline & Španjolska & .08 & .01 & 2.87 \\
\hline & Mađarska & .08 & & 3.00 \\
\hline & Kina & .07 & .01 & 3.07 \\
\hline & $\begin{array}{l}\text { Bosna } \mathrm{i} \\
\text { Hercegovina }\end{array}$ & .06 & & 3.36 \\
\hline
\end{tabular}


Kućar, M., Žauhar, V., Bajšanski, I., Domijan, D., Gulan, T.:

Norme za semantičke kategorije

\begin{tabular}{|c|c|c|c|c|}
\hline Kategorija & Entitet & $\begin{array}{c}\text { Učestalost } \\
\text { pojavljivanja } \\
\text { odgovora }(\mathrm{p})\end{array}$ & $\begin{array}{c}\text { Učestalost } \\
\text { pojavljivanja } \\
\text { odgovora na } 1 . \\
\text { mjestu (p) }\end{array}$ & $\begin{array}{c}\text { Rang } \\
\text { položaja } \\
\text { odgovora }\end{array}$ \\
\hline 22. & Ubojstvo & .98 & .73 & 1.31 \\
\hline \multirow[t]{8}{*}{ Zločin } & Krađa & .83 & .17 & 2.03 \\
\hline & Silovanje & .49 & .02 & 2.88 \\
\hline & Otmica & .22 & & 3.36 \\
\hline & Pljačka & .13 & .03 & 2.36 \\
\hline & Prijevara & .11 & & 3.23 \\
\hline & Provala & .08 & & 3.25 \\
\hline & Nasilje & .05 & & 3.50 \\
\hline & Zlostavljanje & .05 & & 3.60 \\
\hline 23. & Čekić & .73 & .46 & 1.58 \\
\hline \multirow{15}{*}{ Stolarski alat } & Pila & .56 & .17 & 2.14 \\
\hline & Čavao & .29 & .01 & 2.95 \\
\hline & Brusilica & .27 & .06 & 2.62 \\
\hline & Bušilica & .23 & .03 & 2.75 \\
\hline & Brusni papir & .23 & .02 & 2.98 \\
\hline & Dlijeto & .18 & .10 & 1.73 \\
\hline & Odvijač & .14 & .01 & 2.74 \\
\hline & Kliješta & .11 & .02 & 2.70 \\
\hline & Metar & .08 & .01 & 3.33 \\
\hline & Vijak & .07 & .01 & 2.85 \\
\hline & Blanja & .06 & .02 & 2.45 \\
\hline & Sjekira & .06 & .02 & 2.58 \\
\hline & Nož & .06 & .01 & 2.67 \\
\hline & Drvo & .05 & .02 & 2.30 \\
\hline & Svrdlo & .05 & .01 & 2.60 \\
\hline 24. & Svećenik & .79 & .45 & 1.65 \\
\hline Pripadnik & Papa & .62 & .15 & 2.60 \\
\hline \multirow[t]{10}{*}{ svećenstva } & Biskup & .59 & .10 & 2.57 \\
\hline & Časna sestra & .27 & .04 & 2.65 \\
\hline & Kardinal & .25 & .02 & 3.15 \\
\hline & Nadbiskup & .24 & .01 & 3.33 \\
\hline & Fratar & .21 & .09 & 2.10 \\
\hline & Đakon & .13 & .04 & 2.44 \\
\hline & Redovnik & .13 & .02 & 2.44 \\
\hline & Ministrant & .11 & & 2.95 \\
\hline & Pop & .10 & .04 & 1.89 \\
\hline & Župnik & .10 & .03 & 2.63 \\
\hline 25. & Papar & .90 & .22 & 2.16 \\
\hline \multirow[t]{5}{*}{ Začin } & Sol & .87 & .37 & 1.89 \\
\hline & Vegeta & .40 & .08 & 2.84 \\
\hline & Origano & .34 & .13 & 2.52 \\
\hline & Bosiljak & .16 & .04 & 2.75 \\
\hline & Kurkuma & .14 & .03 & 2.93 \\
\hline
\end{tabular}


PSIHOLOGIJSKE TEME, 29 (2020), 3, 649-685

\begin{tabular}{|c|c|c|c|c|}
\hline Kategorija & Entitet & $\begin{array}{c}\text { Učestalost } \\
\text { pojavljivanja } \\
\text { odgovora }(p)\end{array}$ & $\begin{array}{c}\text { Učestalost } \\
\text { pojavljivanja } \\
\text { odgovora na } 1 . \\
\text { mjestu }(\mathrm{p})\end{array}$ & $\begin{array}{c}\text { Rang } \\
\text { položaja } \\
\text { odgovora }\end{array}$ \\
\hline & Čili & .14 & .01 & 3.07 \\
\hline & Peršin & .12 & .04 & 2.67 \\
\hline & Paprika & .12 & .01 & 3.13 \\
\hline & Šećer & .10 & & 3.05 \\
\hline & Cimet & .09 & .02 & 3.11 \\
\hline & Ružmarin & .08 & .01 & 2.93 \\
\hline & Crvena paprika & .08 & & 3.38 \\
\hline & Curry & .06 & .02 & 2.45 \\
\hline 26. & Benzin & .86 & .56 & 1.50 \\
\hline \multirow[t]{11}{*}{ Gorivo } & Dizel & .77 & .19 & 2.02 \\
\hline & Plin & .53 & .04 & 2.91 \\
\hline & Nafta & .43 & .14 & 2.24 \\
\hline & Eurosuper & .15 & .02 & 2.68 \\
\hline & Ugljen & .11 & & 3.60 \\
\hline & Ulje & .09 & & 3.11 \\
\hline & Struja & .09 & & 3.88 \\
\hline & Kerozin & .08 & & 3.13 \\
\hline & Eurodizel & .07 & .02 & 2.15 \\
\hline & Biogorivo & .05 & & 3.40 \\
\hline & Loživo ulje & .05 & & 3.60 \\
\hline \multirow{20}{*}{$\begin{array}{l}27 . \\
\text { Zanimanje }\end{array}$} & Doktor/Liječnik & .60 & .22 & 2.16 \\
\hline & Doktor & .36 & .14 & 2.10 \\
\hline & Liječnik & .24 & .08 & 2.24 \\
\hline & Profesor & .30 & .13 & 1.93 \\
\hline & Učitelj & .27 & .10 & 2.26 \\
\hline & Psiholog & .23 & .09 & 2.16 \\
\hline & Prodavač & .19 & .04 & 2.46 \\
\hline & Odvjetnik & .17 & .02 & 2.63 \\
\hline & Kuhar & .16 & .06 & 2.26 \\
\hline & Policajac & .15 & .03 & 2.66 \\
\hline & Konobar & .13 & .03 & 2.48 \\
\hline & Pravnik & .12 & .02 & 2.48 \\
\hline & Ekonomist & .12 & .02 & 3.09 \\
\hline & Trgovac & .09 & .01 & 3.06 \\
\hline & Vozač & .07 & .02 & 2.71 \\
\hline & Frizer & .07 & .01 & 2.85 \\
\hline & Vatrogasac & .07 & .01 & 3.29 \\
\hline & Automehaničar & .06 & .03 & 2.00 \\
\hline & Stolar & .06 & .02 & 2.25 \\
\hline & Medicinska sestra & .06 & .02 & 2.64 \\
\hline
\end{tabular}


Kućar, M., Žauhar, V., Bajšanski, I., Domijan, D., Gulan, T.:

Norme za semantičke kategorije

\begin{tabular}{|c|c|c|c|c|}
\hline Kategorija & Entitet & $\begin{array}{c}\text { Učestalost } \\
\text { pojavljivanja } \\
\text { odgovora }(p)\end{array}$ & $\begin{array}{c}\text { Učestalost } \\
\text { pojavljivanja } \\
\text { odgovora na } 1 . \\
\text { mjestu (p) }\end{array}$ & $\begin{array}{c}\text { Rang } \\
\text { položaja } \\
\text { odgovora }\end{array}$ \\
\hline \multirow{14}{*}{$\begin{array}{l}28 . \\
\text { Geološka } \\
\text { tvorevina }\end{array}$} & Planina & .60 & .35 & 1.67 \\
\hline & Brdo & .27 & .07 & 2.28 \\
\hline & Stijena & .24 & .16 & 1.60 \\
\hline & Kamen & .20 & .12 & 1.62 \\
\hline & Vulkan & .20 & .05 & 2.35 \\
\hline & Rijeka & .17 & .01 & 2.63 \\
\hline & Jezero & .17 & & 2.79 \\
\hline & Spilja & .16 & .05 & 2.70 \\
\hline & Jama & .12 & .02 & 2.67 \\
\hline & Stalagmit & .09 & .01 & 2.60 \\
\hline & Stalaktit & .08 & .02 & 2.38 \\
\hline & Dolina & .08 & & 3.15 \\
\hline & Otok & .06 & .02 & 2.30 \\
\hline & Zemlja & .06 & .01 & 2.30 \\
\hline \multirow{8}{*}{$\begin{array}{l}29 . \\
\text { Sport }\end{array}$} & Nogomet & .96 & .65 & 1.46 \\
\hline & Rukomet & .78 & .07 & 2.50 \\
\hline & Košarka & .78 & .07 & 2.66 \\
\hline & Odbojka & .48 & .10 & 2.87 \\
\hline & Tenis & .32 & .05 & 3.36 \\
\hline & Plivanje & .13 & .01 & 3.36 \\
\hline & Vaterpolo & .12 & .01 & 3.58 \\
\hline & Atletika & .06 & .01 & 2.50 \\
\hline \multirow{17}{*}{$\begin{array}{l}30 . \\
\text { Meteorološki } \\
\text { fenomen }\end{array}$} & Kiša & .56 & .41 & 1.50 \\
\hline & Snijeg & .43 & & 2.78 \\
\hline & Tuča & .32 & .03 & 2.88 \\
\hline & Tornado & .27 & .07 & 2.42 \\
\hline & Uragan & .20 & .06 & 2.46 \\
\hline & Oluja & .17 & .04 & 2.45 \\
\hline & Vjetar & .17 & .01 & 2.90 \\
\hline & Tsunami & .15 & .03 & 2.46 \\
\hline & Pijavica & .13 & .05 & 2.25 \\
\hline & Grmljavina & .10 & .03 & 2.32 \\
\hline & Bura & .09 & .02 & 2.71 \\
\hline & Sunce & .09 & .01 & 2.31 \\
\hline & Magla & .09 & .01 & 3.06 \\
\hline & Meteor & .07 & .04 & 1.54 \\
\hline & Duga & .07 & .02 & 2.38 \\
\hline & Pomrčina & .07 & .02 & 2.38 \\
\hline & Poplava & .07 & .02 & 2.85 \\
\hline
\end{tabular}


PSIHOLOGIJSKE TEME, 29 (2020), 3, 649-685

\begin{tabular}{|c|c|c|c|c|}
\hline Kategorija & Entitet & $\begin{array}{c}\text { Učestalost } \\
\text { pojavljivanja } \\
\text { odgovora (p) }\end{array}$ & $\begin{array}{c}\text { Učestalost } \\
\text { pojavljivanja } \\
\text { odgovora na } 1 . \\
\text { mjestu (p) }\end{array}$ & $\begin{array}{c}\text { Rang } \\
\text { položaja } \\
\text { odgovora }\end{array}$ \\
\hline 31. & Majica & .93 & .54 & 1.57 \\
\hline Odjevni & Hlače & .92 & .24 & 1.89 \\
\hline \multirow[t]{9}{*}{ predmet } & Jakna & .43 & .05 & 3.10 \\
\hline & Haljina & .37 & .04 & 3.00 \\
\hline & Suknja & .26 & .02 & 3.14 \\
\hline & Košulja & .21 & .05 & 2.66 \\
\hline & Čarape & .16 & & 3.53 \\
\hline & Kaput & .09 & .02 & 2.89 \\
\hline & Gaće & .09 & .01 & 3.44 \\
\hline & Kapa & .09 & & 3.59 \\
\hline & Potkošulja & .07 & .01 & 3.43 \\
\hline 32. & Krov & .74 & .32 & 2.24 \\
\hline \multirow[t]{11}{*}{ Dio građevine } & Zid & .70 & .12 & 2.69 \\
\hline & Vrata & .61 & .09 & 2.51 \\
\hline & Prozor & .58 & .23 & 1.99 \\
\hline & Temelj & .15 & .03 & 2.34 \\
\hline & Stube & .09 & .02 & 2.38 \\
\hline & Balkon & .09 & .02 & 2.88 \\
\hline & Kat & .09 & .01 & 2.81 \\
\hline & Stup & .07 & .01 & 3.29 \\
\hline & Pod & .06 & .01 & 3.64 \\
\hline & Ulaz & .05 & .02 & 2.50 \\
\hline & Dimnjak & .05 & & 3.30 \\
\hline 33. & Kisik & .66 & .33 & 1.87 \\
\hline Kemijski & Vodik & .57 & .15 & 2.23 \\
\hline \multirow[t]{17}{*}{ element } & Dušik & .36 & .02 & 2.91 \\
\hline & Ugljik & .34 & .04 & 2.69 \\
\hline & Natrij & .28 & .10 & 2.48 \\
\hline & Željezo & .18 & .06 & 2.34 \\
\hline & Kalij & .18 & .02 & 2.74 \\
\hline & Helij & .15 & .02 & 2.97 \\
\hline & Sumpor & .14 & .03 & 2.67 \\
\hline & Zlato & .12 & .03 & 2.54 \\
\hline & Kalcij & .12 & .03 & 2.78 \\
\hline & Aluminij & .10 & .03 & 2.37 \\
\hline & Klor & .10 & .02 & 2.42 \\
\hline & Magnezij & .10 & .01 & 3.21 \\
\hline & Srebro & .08 & .03 & 2.25 \\
\hline & Živa & .08 & .02 & 2.93 \\
\hline & Cink & .08 & & 3.44 \\
\hline & Bakar & .06 & .02 & 2.25 \\
\hline & Jod & .06 & & 3.50 \\
\hline
\end{tabular}


Kućar, M., Žauhar, V., Bajšanski, I., Domijan, D., Gulan, T.:

Norme za semantičke kategorije

\begin{tabular}{|c|c|c|c|c|}
\hline Kategorija & Entitet & $\begin{array}{c}\text { Učestalost } \\
\text { pojavljivanja } \\
\text { odgovora }(\mathrm{p})\end{array}$ & $\begin{array}{c}\text { Učestalost } \\
\text { pojavljivanja } \\
\text { odgovora na } 1 . \\
\text { mjestu (p) }\end{array}$ & $\begin{array}{c}\text { Rang } \\
\text { položaja } \\
\text { odgovora }\end{array}$ \\
\hline \multirow{12}{*}{$\begin{array}{l}34 . \\
\text { Glazbeni } \\
\text { instrument }\end{array}$} & Gitara & .92 & .52 & 1.62 \\
\hline & Klavir & .79 & .21 & 2.13 \\
\hline & Violina & .63 & .15 & 2.66 \\
\hline & Bubnjevi & .49 & .01 & 3.09 \\
\hline & Truba & .28 & .07 & 2.75 \\
\hline & Flauta & .17 & .01 & 3.19 \\
\hline & Harmonika & .12 & .02 & 2.92 \\
\hline & Violončelo & .12 & & 3.33 \\
\hline & Frula & .08 & .02 & 2.88 \\
\hline & Saksofon & .08 & & 3.53 \\
\hline & Bas-gitara & .05 & & 3.10 \\
\hline & Kontrabas & .05 & & 3.20 \\
\hline \multirow{13}{*}{$\begin{array}{l}35 . \\
\text { Vrsta novca }\end{array}$} & Kuna & .88 & .52 & 1.73 \\
\hline & Euro & .88 & .20 & 2.18 \\
\hline & Dolar & .75 & .14 & 2.49 \\
\hline & Funta & .31 & & 3.53 \\
\hline & Dinar & .16 & .01 & 3.32 \\
\hline & Marka & .14 & & 3.41 \\
\hline & Kruna & .13 & .01 & 3.36 \\
\hline & Kovanica & .10 & .03 & 2.05 \\
\hline & Franak & .10 & .01 & 3.30 \\
\hline & Novčanica & .06 & .03 & 1.55 \\
\hline & Papirnati novac & .06 & .03 & 1.67 \\
\hline & Jen & .06 & .01 & 3.42 \\
\hline & Forinta & .05 & & 3.80 \\
\hline \multirow{13}{*}{$\begin{array}{l}36 . \\
\text { Vrsta glazbe }\end{array}$} & Rock & .94 & .52 & 1.59 \\
\hline & Pop & .79 & .30 & 1.91 \\
\hline & $J a z z$ & .42 & .06 & 2.94 \\
\hline & Metal & .31 & .02 & 2.95 \\
\hline & Rap & .27 & .02 & 3.10 \\
\hline & Klasična glazba & .16 & .02 & 3.00 \\
\hline & Punk & .14 & .01 & 2.85 \\
\hline & Folk & .11 & & 3.45 \\
\hline & Blues & .10 & .01 & 3.15 \\
\hline & $R^{\prime} n^{\prime} B$ & .09 & .01 & 3.11 \\
\hline & Techno & .09 & .01 & 3.22 \\
\hline & Narodna glazba & .08 & .01 & 2.87 \\
\hline & Country & .06 & & 3.64 \\
\hline
\end{tabular}


PSIHOLOGIJSKE TEME, 29 (2020), 3, 649-685

\begin{tabular}{|c|c|c|c|c|}
\hline Kategorija & Entitet & $\begin{array}{c}\text { Učestalost } \\
\text { pojavljivanja } \\
\text { odgovora }(p)\end{array}$ & $\begin{array}{c}\text { Učestalost } \\
\text { pojavljivanja } \\
\text { odgovora na } 1 . \\
\text { mjestu (p) }\end{array}$ & $\begin{array}{c}\text { Rang } \\
\text { položaja } \\
\text { odgovora }\end{array}$ \\
\hline 37. & Vrabac & .60 & .26 & 1.97 \\
\hline \multirow{12}{*}{ Ptica } & Galeb & .55 & .06 & 2.84 \\
\hline & Golub & .51 & .07 & 2.72 \\
\hline & Kos & .32 & .15 & 2.10 \\
\hline & Lastavica & .30 & .12 & 2.16 \\
\hline & Orao & .30 & .09 & 2.47 \\
\hline & Vrana & .21 & .01 & 2.88 \\
\hline & Roda & .14 & .04 & 2.31 \\
\hline & Slavuj & .13 & .02 & 2.58 \\
\hline & Sova & .13 & .02 & 2.71 \\
\hline & Papiga & .13 & .02 & 2.83 \\
\hline & Sokol & .11 & .02 & 2.67 \\
\hline & Jastreb & .05 & .01 & 3.10 \\
\hline 38. & Voda & .74 & .30 & 1.99 \\
\hline Bezalkoholno & Sok & .72 & .28 & 2.02 \\
\hline \multirow[t]{11}{*}{ piće } & Coca-Cola & .48 & .23 & 1.84 \\
\hline & Fanta & .29 & .02 & 2.84 \\
\hline & Kava & .27 & .01 & 3.32 \\
\hline & Cedevita & .25 & .09 & 2.18 \\
\hline & Čaj & .22 & .02 & 3.05 \\
\hline & Sprite & .19 & .01 & 2.95 \\
\hline & Mineralna voda & .19 & .01 & 3.39 \\
\hline & Mlijeko & .13 & .01 & 3.52 \\
\hline & Limunada & .12 & .02 & 2.74 \\
\hline & Gazirano piće & .08 & .01 & 3.00 \\
\hline & Ledeni čaj & .07 & & 3.08 \\
\hline 39. & Automobil & .99 & .94 & 1.08 \\
\hline \multirow[t]{9}{*}{ Vozilo } & Autobus & .61 & .02 & 2.51 \\
\hline & Motor & .55 & .01 & 2.86 \\
\hline & Kamion & .38 & .01 & 2.93 \\
\hline & Bicikl & .29 & .01 & 3.09 \\
\hline & Vlak & .27 & & 3.29 \\
\hline & Avion & .26 & & 3.37 \\
\hline & Tramvaj & .15 & & 3.39 \\
\hline & Kombi & .13 & & 2.96 \\
\hline & Brod & .13 & & 3.24 \\
\hline 40. & Fizika & .76 & .21 & 2.20 \\
\hline \multirow[t]{6}{*}{ Znanost } & Kemija & .70 & .13 & 2.47 \\
\hline & Biologija & .66 & .12 & 2.79 \\
\hline & Matematika & .48 & .13 & 2.49 \\
\hline & Psihologija & .40 & .19 & 2.12 \\
\hline & Medicina & .18 & .07 & 2.24 \\
\hline & Astronomija & .06 & .02 & 2.92 \\
\hline
\end{tabular}


Kućar, M., Žauhar, V., Bajšanski, I., Domijan, D., Gulan, T.:

Norme za semantičke kategorije

\begin{tabular}{|c|c|c|c|c|}
\hline Kategorija & Entitet & $\begin{array}{c}\text { Učestalost } \\
\text { pojavljivanja } \\
\text { odgovora }(\mathrm{p})\end{array}$ & $\begin{array}{c}\text { Učestalost } \\
\text { pojavljivanja } \\
\text { odgovora na } 1 . \\
\text { mjestu (p) }\end{array}$ & $\begin{array}{c}\text { Rang } \\
\text { položaja } \\
\text { odgovora }\end{array}$ \\
\hline & Prirodna znanost & .05 & .03 & 2.10 \\
\hline & Geografija & .05 & .01 & 2.80 \\
\hline & Informatika & .05 & .01 & 3.60 \\
\hline 41. & Lutka & .69 & .24 & 2.02 \\
\hline \multirow[t]{11}{*}{ Igračka } & Autić & .55 & .20 & 2.09 \\
\hline & Medvjedić & .35 & .16 & 1.93 \\
\hline & Barbie & .35 & .07 & 2.56 \\
\hline & Lopta & .34 & .09 & 2.52 \\
\hline & LEGO kocke & .24 & .03 & 3.00 \\
\hline & Auto & .21 & .06 & 2.23 \\
\hline & Plišana igračka & .19 & .07 & 2.22 \\
\hline & Zvečka & .12 & .03 & 2.96 \\
\hline & Puzzle & .11 & .01 & 3.62 \\
\hline & Kocka & .07 & .01 & 3.00 \\
\hline & Kockice & .06 & & 3.25 \\
\hline 42. & Valcer & .82 & .19 & 2.34 \\
\hline \multirow[t]{13}{*}{ Ples } & Tango & .73 & .40 & 1.79 \\
\hline & Salsa & .34 & .09 & 2.35 \\
\hline & Samba & .29 & .07 & 2.48 \\
\hline & Hip-hop & .24 & .05 & 2.78 \\
\hline & Cha-cha-cha & .24 & .02 & 3.11 \\
\hline & Balet & .22 & .06 & 2.40 \\
\hline & Zumba & .13 & .02 & 2.67 \\
\hline & Rumba & .13 & .02 & 2.88 \\
\hline & $J a z z$ & .11 & .02 & 2.67 \\
\hline & Suvremeni ples & .11 & .02 & 2.77 \\
\hline & Polka & .08 & .01 & 3.06 \\
\hline & Folklor & .05 & .01 & 3.30 \\
\hline & Break-dance & .05 & & 3.50 \\
\hline 43. & Mrkva & .54 & .21 & 2.23 \\
\hline \multirow[t]{12}{*}{ Povrće } & Krumpir & .42 & .07 & 2.54 \\
\hline & $\begin{array}{l}\text { Salata/Zelena } \\
\text { salata }\end{array}$ & .41 & .12 & 2.39 \\
\hline & Salata & .33 & .10 & 2.34 \\
\hline & Zelena salata & .08 & .02 & 2.60 \\
\hline & Rajčica & .34 & .09 & 2.28 \\
\hline & Brokula & .26 & .08 & 2.26 \\
\hline & Paprika & .26 & .06 & 2.45 \\
\hline & Krastavac & .25 & .05 & 2.67 \\
\hline & Kupus & .21 & .06 & 2.35 \\
\hline & Luk & .18 & .02 & 2.94 \\
\hline & Tikvica & .17 & .03 & 2.78 \\
\hline & Blitva & .16 & .09 & 1.84 \\
\hline
\end{tabular}


PSIHOLOGIJSKE TEME, 29 (2020), 3, 649-685

\begin{tabular}{|c|c|c|c|c|}
\hline Kategorija & Entitet & $\begin{array}{c}\text { Učestalost } \\
\text { pojavljivanja } \\
\text { odgovora }(\mathrm{p})\end{array}$ & $\begin{array}{c}\text { Učestalost } \\
\text { pojavljivanja } \\
\text { odgovora na } 1 . \\
\text { mjestu (p) }\end{array}$ & $\begin{array}{c}\text { Rang } \\
\text { položaja } \\
\text { odgovora }\end{array}$ \\
\hline & Kelj & .11 & .03 & 2.45 \\
\hline & Špinat & .09 & .04 & 2.06 \\
\hline & Cvjetača & .08 & .01 & 2.87 \\
\hline & Patlidžan & .06 & .01 & 3.36 \\
\hline & Grašak & .06 & & 2.50 \\
\hline & Cikla & .06 & & 3.25 \\
\hline & Celer & .06 & & 3.33 \\
\hline 44. & Tenisice/Patike & .93 & .52 & 1.62 \\
\hline \multirow[t]{9}{*}{ Obuća } & Tenisice & .75 & .41 & 1.65 \\
\hline & Patike & .18 & .11 & 1.50 \\
\hline & Štikle & .63 & .09 & 2.72 \\
\hline & Čizme & .61 & .05 & 2.69 \\
\hline & Cipele & .60 & .28 & 1.95 \\
\hline & Sandale & .38 & .02 & 3.18 \\
\hline & Japanke & .28 & .01 & 3.48 \\
\hline & Balerinke & .20 & & 3.21 \\
\hline & Papuče & .18 & & 3.26 \\
\hline 45. & Pčela & .43 & .07 & 2.65 \\
\hline \multirow[t]{13}{*}{ Kukac } & Muha & .41 & .13 & 2.30 \\
\hline & Komarac & .39 & .07 & 2.60 \\
\hline & Pauk & .37 & .11 & 2.35 \\
\hline & Mrav & .37 & .10 & 2.28 \\
\hline & Žohar & .33 & .12 & 2.14 \\
\hline & Skakavac & .33 & .12 & 2.14 \\
\hline & Bubamara & .30 & .13 & 2.09 \\
\hline & Osa & .22 & .05 & 2.60 \\
\hline & Leptir & .20 & .02 & 3.11 \\
\hline & Bogomoljka & .10 & .02 & 2.53 \\
\hline & Stonoga & .09 & .01 & 3.12 \\
\hline & Bumbar & .07 & .01 & 3.29 \\
\hline & Smrdljivi martin & .06 & .02 & 2.67 \\
\hline 46. & Ana & .65 & .38 & 1.71 \\
\hline \multirow[t]{11}{*}{ Žensko ime } & Ivana & .51 & .15 & 2.27 \\
\hline & Marija & .46 & .08 & 2.23 \\
\hline & Maja & .28 & .09 & 2.22 \\
\hline & Lucija & .25 & .03 & 3.04 \\
\hline & Iva & .21 & .03 & 2.65 \\
\hline & Petra & .12 & .01 & 3.00 \\
\hline & Sara & .10 & .02 & 3.20 \\
\hline & Mia & .09 & & 3.41 \\
\hline & Martina & .07 & .02 & 2.54 \\
\hline & Karla & .07 & .02 & 2.64 \\
\hline & Katarina & .07 & .01 & 2.92 \\
\hline
\end{tabular}


Kućar, M., Žauhar, V., Bajšanski, I., Domijan, D., Gulan, T.:

Norme za semantičke kategorije

\begin{tabular}{|c|c|c|c|c|}
\hline Kategorija & Entitet & $\begin{array}{c}\text { Učestalost } \\
\text { pojavljivanja } \\
\text { odgovora }(p)\end{array}$ & $\begin{array}{c}\text { Učestalost } \\
\text { pojavljivanja } \\
\text { odgovora na } 1 . \\
\text { mjestu (p) }\end{array}$ & $\begin{array}{c}\text { Rang } \\
\text { položaja } \\
\text { odgovora }\end{array}$ \\
\hline & Tea & .07 & .01 & 3.00 \\
\hline & Josipa & .05 & & 3.20 \\
\hline 47. & Ivan & .84 & .43 & 1.82 \\
\hline \multirow[t]{10}{*}{ Muško ime } & Marko & .69 & .21 & 2.17 \\
\hline & Luka & .54 & .07 & 2.67 \\
\hline & Petar & .19 & .01 & 3.00 \\
\hline & Matej & .15 & .02 & 2.86 \\
\hline & Karlo & .11 & .01 & 3.05 \\
\hline & Josip & .11 & .01 & 3.23 \\
\hline & Ante & .10 & .03 & 2.58 \\
\hline & Matija & .09 & .03 & 2.61 \\
\hline & Filip & .07 & .01 & 3.23 \\
\hline & David & .05 & .01 & 2.90 \\
\hline 48. & Ruža & .79 & .38 & 1.82 \\
\hline \multirow[t]{13}{*}{ Cvijet } & Tratinčica & .55 & .15 & 2.36 \\
\hline & Tulipan & .45 & .08 & 2.41 \\
\hline & Maslačak & .37 & .08 & 2.54 \\
\hline & Visibaba & .29 & .07 & 2.72 \\
\hline & Ljubičica & .28 & .05 & 2.67 \\
\hline & Jaglac & .19 & .05 & 2.68 \\
\hline & Orhideja & .19 & .03 & 3.11 \\
\hline & Narcis & .13 & .02 & 2.96 \\
\hline & Suncokret & .11 & .02 & 2.91 \\
\hline & Maćuhica & .07 & .01 & 2.79 \\
\hline & Ljiljan & .07 & .01 & 2.85 \\
\hline & Šafran & .05 & .01 & 2.80 \\
\hline & Karanfil & .05 & .01 & 3.30 \\
\hline 49. & Gripa & .57 & .24 & 1.92 \\
\hline \multirow[t]{14}{*}{ Bolest } & Rak/Karcinom & .46 & .16 & 2.24 \\
\hline & Rak & .37 & .13 & 2.25 \\
\hline & Karcinom & .09 & .03 & 2.18 \\
\hline & Prehlada & .42 & .15 & 2.00 \\
\hline & Upala pluća & .21 & .04 & 2.75 \\
\hline & AIDS & .18 & .03 & 2.74 \\
\hline & Viroza & .15 & .02 & 2.93 \\
\hline & Tumor & .14 & .04 & 2.39 \\
\hline & Dijabetes & .10 & .03 & 2.40 \\
\hline & Tuberkuloza & .09 & .02 & 2.53 \\
\hline & Mononukleoza & .09 & .02 & 2.71 \\
\hline & $\begin{array}{l}\text { Alzheimerova } \\
\text { bolest }\end{array}$ & .08 & .02 & 2.33 \\
\hline & Vodene kozice & .08 & .02 & 2.73 \\
\hline & Leukemija & .08 & .02 & 2.88 \\
\hline
\end{tabular}


PSIHOLOGIJSKE TEME, 29 (2020), 3, 649-685

\begin{tabular}{|c|c|c|c|c|}
\hline Kategorija & Entitet & $\begin{array}{c}\text { Učestalost } \\
\text { pojavljivanja } \\
\text { odgovora (p) }\end{array}$ & $\begin{array}{c}\text { Učestalost } \\
\text { pojavljivanja } \\
\text { odgovora na } 1 . \\
\text { mjestu (p) }\end{array}$ & $\begin{array}{c}\text { Rang } \\
\text { položaja } \\
\text { odgovora }\end{array}$ \\
\hline & Kuga & .07 & .04 & 1.86 \\
\hline & Upala & .07 & .01 & 2.85 \\
\hline & Upala grla & .06 & .01 & 3.17 \\
\hline 50. & Hrast & .74 & .46 & 1.61 \\
\hline \multirow[t]{14}{*}{ Stablo } & Bor & .59 & .07 & 2.89 \\
\hline & Jela & .37 & .04 & 2.93 \\
\hline & Bukva & .31 & .04 & 2.22 \\
\hline & Smreka & .23 & .02 & 3.05 \\
\hline & Lipa & .22 & .06 & 2.52 \\
\hline & Vrba & .20 & .06 & 2.46 \\
\hline & Breza & .17 & .03 & 2.59 \\
\hline & Trešnja & .13 & .02 & 2.63 \\
\hline & Jabuka & .12 & .06 & 2.39 \\
\hline & Čempres & .11 & .03 & 2.62 \\
\hline & Orah & .10 & .03 & 2.32 \\
\hline & Javor & .06 & .01 & 2.45 \\
\hline & Maslina & .06 & .01 & 3.17 \\
\hline & Kesten & .06 & & 3.25 \\
\hline 51. & Jahta & .43 & .15 & 2.23 \\
\hline \multirow[t]{13}{*}{ Brod } & Jedrilica & .42 & .11 & 2.54 \\
\hline & Trajekt & .41 & .08 & 2.51 \\
\hline & Kruzer & .36 & .07 & 2.56 \\
\hline & Čamac & .31 & .11 & 2.43 \\
\hline & Katamaran & .29 & .02 & 2.78 \\
\hline & Barka & .24 & .08 & 2.35 \\
\hline & Teretni brod & .24 & .05 & 2.63 \\
\hline & Gliser & .21 & .03 & 2.51 \\
\hline & Tanker & .19 & .08 & 1.95 \\
\hline & Putnički brod & .10 & .03 & 2.11 \\
\hline & Titanic & .07 & .04 & 2.00 \\
\hline & Ribarski brod & .07 & .02 & 2.79 \\
\hline & Jedrenjak & .05 & .03 & 2.30 \\
\hline 52. & Srdela & .55 & .16 & 2.43 \\
\hline \multirow[t]{10}{*}{ Riba } & Tuna & .44 & .11 & 2.32 \\
\hline & Pastrva & .33 & .10 & 2.30 \\
\hline & Šaran & .30 & .13 & 1.97 \\
\hline & Orada & .27 & .09 & 2.29 \\
\hline & Som & .27 & .08 & 2.45 \\
\hline & Oslić & .24 & .04 & 2.68 \\
\hline & Skuša & .18 & .06 & 2.43 \\
\hline & Brancin & .16 & .03 & 2.40 \\
\hline & Morski pas & .16 & .02 & 2.77 \\
\hline & Losos & .13 & .02 & 2.75 \\
\hline
\end{tabular}


Kućar, M., Žauhar, V., Bajšanski, I., Domijan, D., Gulan, T.:

Norme za semantičke kategorije

\begin{tabular}{|c|c|c|c|c|}
\hline Kategorija & Entitet & $\begin{array}{c}\text { Učestalost } \\
\text { pojavljivanja } \\
\text { odgovora (p) }\end{array}$ & $\begin{array}{c}\text { Učestalost } \\
\text { pojavljivanja } \\
\text { odgovora na } 1 . \\
\text { mjestu (p) }\end{array}$ & $\begin{array}{c}\text { Rang } \\
\text { položaja } \\
\text { odgovora }\end{array}$ \\
\hline & Štuka & .09 & .02 & 2.50 \\
\hline & Inćun & .08 & .01 & 2.87 \\
\hline & Škarpina & .06 & .01 & 3.42 \\
\hline & Zubatac & .05 & .03 & 2.00 \\
\hline 53. & Poskok & .77 & .43 & 1.76 \\
\hline \multirow[t]{10}{*}{ Zmija } & Anakonda & .45 & .08 & 2.63 \\
\hline & Kobra & .44 & .13 & 2.33 \\
\hline & Bjelouška & .32 & .06 & 2.46 \\
\hline & Piton & .31 & .06 & 2.73 \\
\hline & Udav & .28 & .04 & 2.62 \\
\hline & Čegrtuša & .27 & .08 & 2.40 \\
\hline & Riđovka & .23 & .04 & 2.41 \\
\hline & Sljepić & .15 & .02 & 2.93 \\
\hline & Mamba & .08 & & 2.81 \\
\hline & Boa & .07 & .01 & 2.92 \\
\hline 54. & Zagreb & .72 & .29 & 1.86 \\
\hline \multirow[t]{14}{*}{ Grad } & Rijeka & .66 & .31 & 1.86 \\
\hline & Split & .41 & .03 & 3.03 \\
\hline & London & .27 & .06 & 2.48 \\
\hline & New York & .26 & .08 & 2.32 \\
\hline & Osijek & .23 & & 3.58 \\
\hline & Pariz & .21 & .02 & 2.95 \\
\hline & Varaždin & .09 & .03 & 2.35 \\
\hline & Zadar & .08 & .02 & 2.47 \\
\hline & Pula & .08 & .02 & 3.00 \\
\hline & Berlin & .08 & .01 & 2.53 \\
\hline & Tokio & .06 & .02 & 2.82 \\
\hline & Amsterdam & .06 & .01 & 3.08 \\
\hline & Rim & .06 & & 3.18 \\
\hline & Dubrovnik & .06 & & 3.64 \\
\hline 55. & Aspirin & .47 & .30 & 1.64 \\
\hline \multirow[t]{12}{*}{ Lijek } & Lupocet & .28 & .05 & 2.41 \\
\hline & Neofen & .25 & .02 & 2.73 \\
\hline & Lekadol & .23 & .06 & 2.51 \\
\hline & Brufen & .22 & .05 & 2.33 \\
\hline & Antibiotik & .20 & .10 & 1.97 \\
\hline & Sirup & .17 & .03 & 2.44 \\
\hline & Andol & .16 & .06 & 2.26 \\
\hline & Tableta & .13 & .06 & 1.80 \\
\hline & Penicilin & .12 & .06 & 2.09 \\
\hline & Ibuprofen & .10 & .02 & 2.65 \\
\hline & Paracetamol & .06 & .03 & 1.75 \\
\hline & Sumamed & .06 & .02 & 2.45 \\
\hline
\end{tabular}


PSIHOLOGIJSKE TEME, 29 (2020), 3, 649-685

\begin{tabular}{|c|c|c|c|c|}
\hline Kategorija & Entitet & $\begin{array}{c}\text { Učestalost } \\
\text { pojavljivanja } \\
\text { odgovora (p) }\end{array}$ & $\begin{array}{c}\text { Učestalost } \\
\text { pojavljivanja } \\
\text { odgovora na } 1 . \\
\text { mjestu (p) }\end{array}$ & $\begin{array}{c}\text { Rang } \\
\text { položaja } \\
\text { odgovora }\end{array}$ \\
\hline & Normabel & .06 & .01 & 3.33 \\
\hline & Klavocin & .05 & .01 & 2.70 \\
\hline 56. & $B M W$ & .59 & .15 & 2.31 \\
\hline \multirow[t]{15}{*}{ Automobil } & Mercedes & .52 & .15 & 2.29 \\
\hline & Audi & .51 & .12 & 2.29 \\
\hline & Renault & .22 & .05 & 2.60 \\
\hline & Fiat & .21 & .05 & 2.73 \\
\hline & Opel & .20 & .07 & 2.33 \\
\hline & Ford & .17 & .06 & 2.09 \\
\hline & Volkswagen & .17 & .01 & 2.84 \\
\hline & Peugeot & .14 & .04 & 2.65 \\
\hline & Golf & .10 & .05 & 2.25 \\
\hline & Citroen & .09 & .04 & 2.28 \\
\hline & Ferrari & .09 & .03 & 2.59 \\
\hline & Škoda & .09 & .01 & 2.83 \\
\hline & Toyota & .08 & .01 & 2.94 \\
\hline & Mazda & .07 & .01 & 2.50 \\
\hline & Porsche & .05 & .01 & 3.00 \\
\hline \multirow{13}{*}{$\begin{array}{l}57 . \\
\text { Tekućina }\end{array}$} & Voda & .99 & .96 & 1.03 \\
\hline & Sok & .78 & .02 & 2.49 \\
\hline & Alkohol & .23 & & 2.98 \\
\hline & Vino & .21 & & 3.27 \\
\hline & Mlijeko & .19 & .01 & 2.89 \\
\hline & Pivo & .17 & & 3.16 \\
\hline & More & .13 & & 2.80 \\
\hline & Ulje & .13 & & 2.80 \\
\hline & Krv & .11 & & 2.86 \\
\hline & Čaj & .11 & & 3.27 \\
\hline & Kava & .09 & & 3.61 \\
\hline & Nafta & .08 & & 2.88 \\
\hline & Benzin & .07 & & 3.38 \\
\hline \multirow{11}{*}{$\begin{array}{l}58 . \\
\text { Ženska odjeća }\end{array}$} & Haljina & .92 & .58 & 1.66 \\
\hline & Suknja & .89 & .18 & 2.17 \\
\hline & Majica & .33 & .10 & 2.41 \\
\hline & Grudnjak & .33 & .03 & 3.00 \\
\hline & Hlače & .25 & .01 & 3.18 \\
\hline & Košulja & .17 & .01 & 3.09 \\
\hline & Bluza & .13 & .02 & 2.76 \\
\hline & Najlonke & .12 & & 3.43 \\
\hline & Štikle & .11 & .02 & 2.81 \\
\hline & Tajice & .07 & & 3.29 \\
\hline & Kombinezon & .05 & & 3.40 \\
\hline
\end{tabular}


Kućar, M., Žauhar, V., Bajšanski, I., Domijan, D., Gulan, T.:

Norme za semantičke kategorije

\begin{tabular}{|c|c|c|c|c|}
\hline Kategorija & Entitet & $\begin{array}{c}\text { Učestalost } \\
\text { pojavljivanja } \\
\text { odgovora }(p)\end{array}$ & $\begin{array}{c}\text { Učestalost } \\
\text { pojavljivanja } \\
\text { odgovora na } 1 . \\
\text { mjestu (p) }\end{array}$ & $\begin{array}{c}\text { Rang } \\
\text { položaja } \\
\text { odgovora }\end{array}$ \\
\hline 59. & Avion & .93 & .77 & 1.23 \\
\hline \multirow[t]{16}{*}{ Objekt koji leti } & Helikopter & .76 & .02 & 2.44 \\
\hline & Ptica & .26 & .07 & 2.39 \\
\hline & Dron & .26 & .01 & 3.02 \\
\hline & Balon & .25 & .01 & 3.08 \\
\hline & Raketa & .19 & & 3.19 \\
\hline & Zmaj & .15 & .02 & 3.03 \\
\hline & Zrakoplov & .10 & .06 & 1.65 \\
\hline & Cepelin & .09 & & 3.47 \\
\hline & NLO & .07 & .02 & 2.54 \\
\hline & Frizbi & .07 & .01 & 2.86 \\
\hline & Padobran & .07 & .01 & 2.93 \\
\hline & Bumerang & .07 & .01 & 3.08 \\
\hline & Svemirski brod & .07 & & 3.54 \\
\hline & Satelit & .06 & & 3.36 \\
\hline & Letjelica & .06 & & 3.75 \\
\hline & Lopta & .05 & .01 & 2.70 \\
\hline \multirow{19}{*}{$\begin{array}{l}60 . \\
\text { Predmet koji } \\
\text { stvara buku }\end{array}$} & Bubnjevi & .31 & .15 & 1.95 \\
\hline & Automobil & .30 & .09 & 2.31 \\
\hline & Zvučnik & .27 & .12 & 2.06 \\
\hline & Bušilica & .24 & .08 & 2.07 \\
\hline & Radio & .15 & .04 & 2.72 \\
\hline & Televizor & .15 & .01 & 2.86 \\
\hline & Avion & .13 & .04 & 2.16 \\
\hline & Usisavač & .13 & .02 & 2.60 \\
\hline & Truba & .12 & .05 & 2.04 \\
\hline & Zvono & .12 & .04 & 2.13 \\
\hline & Motor & .12 & .02 & 2.88 \\
\hline & Mobitel & .09 & .04 & 2.22 \\
\hline & Kosilica & .09 & .01 & 3.18 \\
\hline & Čekić & .08 & .01 & 2.75 \\
\hline & $\begin{array}{l}\text { Glazbeni } \\
\text { instrument }\end{array}$ & .07 & .02 & 2.43 \\
\hline & Sirena & .07 & .02 & 2.46 \\
\hline & Perilica & .07 & .02 & 2.57 \\
\hline & Mikser & .07 & & 2.86 \\
\hline & Alarm & .06 & .01 & 2.50 \\
\hline 61. & Stol & .91 & .55 & 1.65 \\
\hline \multirow[t]{5}{*}{ Drveni predmet } & Stolica & .78 & .09 & 2.24 \\
\hline & Ormar & .37 & .03 & 3.13 \\
\hline & Kuhača & .30 & .14 & 2.07 \\
\hline & Olovka & .16 & .07 & 2.13 \\
\hline & Krevet & .16 & .01 & 3.17 \\
\hline
\end{tabular}


PSIHOLOGIJSKE TEME, 29 (2020), 3, 649-685

\begin{tabular}{|c|c|c|c|c|}
\hline Kategorija & Entitet & $\begin{array}{c}\text { Učestalost } \\
\text { pojavljivanja } \\
\text { odgovora (p) }\end{array}$ & $\begin{array}{c}\text { Učestalost } \\
\text { pojavljivanja } \\
\text { odgovora na } 1 . \\
\text { mjestu (p) }\end{array}$ & $\begin{array}{c}\text { Rang } \\
\text { položaja } \\
\text { odgovora }\end{array}$ \\
\hline & Vrata & .15 & .02 & 3.14 \\
\hline & Klupa & .12 & .02 & 2.91 \\
\hline & Stolac & .09 & .02 & 2.50 \\
\hline & Daska & .08 & .01 & 2.80 \\
\hline & Polica & .07 & & 3.46 \\
\hline 62. & Mobitel & .52 & .14 & 2.29 \\
\hline \multirow{13}{*}{$\begin{array}{l}\text { Predmet koji } \\
\text { iznosimo iz } \\
\text { kuće u plamenu }\end{array}$} & Novac & .39 & .18 & 1.96 \\
\hline & Laptop & .35 & .12 & 2.20 \\
\hline & Novčanik & .25 & .13 & 1.86 \\
\hline & Dokumenti & .23 & .07 & 2.38 \\
\hline & Odjeća & .18 & .01 & 3.09 \\
\hline & Nakit & .15 & & 3.04 \\
\hline & Fotoalbum & .14 & .05 & 2.08 \\
\hline & Slike & .14 & .03 & 2.67 \\
\hline & Televizor & .10 & .02 & 2.72 \\
\hline & Knjige & .10 & .02 & 2.89 \\
\hline & Računalo & .09 & .02 & 2.75 \\
\hline & Tava & .06 & .03 & 1.91 \\
\hline & Fotografije & .06 & .01 & 2.40 \\
\hline 63. & Lopata & .70 & .29 & 1.83 \\
\hline \multirow[t]{11}{*}{ Vrtlarski alat } & Grablje & .65 & .21 & 2.17 \\
\hline & Motika & .47 & .20 & 1.96 \\
\hline & Škare & .47 & .19 & 2.25 \\
\hline & Kosilica & .22 & .01 & 2.84 \\
\hline & Rukavice & .16 & & 3.23 \\
\hline & Lopatica & .11 & .05 & 1.86 \\
\hline & Kanta & .11 & .01 & 3.27 \\
\hline & Vile & .11 & & 3.18 \\
\hline & Kantica & .09 & .01 & 3.18 \\
\hline & Kramp & .07 & .01 & 3.14 \\
\hline & Štihača & .07 & & 3.00 \\
\hline 64. & Trava & .28 & .08 & 2.49 \\
\hline \multirow[t]{11}{*}{ Biljka } & Ruža & .27 & .08 & 2.29 \\
\hline & Tratinčica & .23 & .10 & 2.00 \\
\hline & Cvijet & .22 & .12 & 1.79 \\
\hline & Maslačak & .21 & .03 & 2.58 \\
\hline & Hrast & .13 & .06 & 1.88 \\
\hline & Visibaba & .13 & .04 & 2.46 \\
\hline & Drvo & .12 & .04 & 1.95 \\
\hline & Tulipan & .12 & .01 & 3.05 \\
\hline & Jaglac & .10 & .02 & 2.89 \\
\hline & Stablo & .09 & .02 & 2.29 \\
\hline & Grm & .09 & .01 & 3.12 \\
\hline
\end{tabular}


Kućar, M., Žauhar, V., Bajšanski, I., Domijan, D., Gulan, T.:

Norme za semantičke kategorije

\begin{tabular}{|c|c|c|c|c|}
\hline Kategorija & Entitet & $\begin{array}{c}\text { Učestalost } \\
\text { pojavljivanja } \\
\text { odgovora }(\mathrm{p})\end{array}$ & $\begin{array}{c}\text { Učestalost } \\
\text { pojavljivanja } \\
\text { odgovora na } 1 . \\
\text { mjestu (p) }\end{array}$ & $\begin{array}{c}\text { Rang } \\
\text { položaja } \\
\text { odgovora }\end{array}$ \\
\hline & Ljubičica & .08 & .03 & 2.38 \\
\hline & Orhideja & .08 & .02 & 2.63 \\
\hline & Kaktus & .07 & .03 & 1.93 \\
\hline & Salata & .07 & .02 & 2.23 \\
\hline & Ružmarin & .05 & .01 & 2.50 \\
\hline & Bor & .05 & .01 & 2.80 \\
\hline & Jabuka & .05 & & 3.10 \\
\hline 65. & Zagreb & .94 & .50 & 1.62 \\
\hline \multirow[t]{7}{*}{ Hrvatski grad } & Rijeka & .94 & .29 & 2.16 \\
\hline & Split & .78 & .06 & 3.04 \\
\hline & Osijek & .44 & .01 & 3.34 \\
\hline & Zadar & .26 & .02 & 3.18 \\
\hline & Dubrovnik & .13 & .01 & 3.48 \\
\hline & Varaždin & .10 & .03 & 2.63 \\
\hline & Pula & .09 & .03 & 2.72 \\
\hline 66. & Pas & 1.00 & .83 & 1.19 \\
\hline \multirow[t]{9}{*}{ Kućni ljubimac } & Mačka & 1.00 & .16 & 1.88 \\
\hline & Ribica & .50 & & 3.42 \\
\hline & Hrčak & .45 & & 3.51 \\
\hline & Papiga & .33 & .01 & 3.51 \\
\hline & Zec & .26 & .01 & 3.20 \\
\hline & Kornjača & .14 & & 3.63 \\
\hline & Ptica & .08 & & 3.53 \\
\hline & Kunić & .07 & & 3.08 \\
\hline & Zamorac & .06 & & 3.67 \\
\hline
\end{tabular}

Napomena: Popis svih prikupljenih entiteta pojedine kategorije moguće je dobiti na upit. 
